\title{
COVID-19 Pandemi Sürecinde Kentsel Hareketlilik: Dünya Örnekleri ve Ankara Deneyimleri
}

\author{
Şerife Özcan ${ }^{1}$ \\ ORCID: 0000-0003-3268-1528
}

\author{
Cenk Hamamcioğlu² \\ ORCID: 0000-0002-3872-4608
}

Öz

Aralık 2019 yılının başlarında Çin'in Vuhan kentinden bildirilen ve sonrasında dünyaya hızla yayılan COVID-19 pandemisi, günlük hayatın akışında çarpıcı etkilere neden olmuştur. Sağlık endişelerinin etkisiyle fiziksel mesafe kavramını hayata girmesi ve tam kapanma gibi süreçlerle günlük yaşam ve alışkanlıklar yeniden şekillenmeye başlamıştır. Yeniden şekillenen durumlardan biri de değişsen seyahat davranışları ve kentsel hareketliliktir. Kentsel hareketliliğin azalarak hayatın mahalle ölçeğinde yaşanması ve genellikle yürüme mesafesinde ihtiyaçların karşılanması veya toplu taşımanın daha az tercih edilir olması değişiklikler arasında görülebilir. Bu süreçle birlikte dünyanın farklı kentlerinde hareketliliğin să̆lıkl, güvenli ve herkes için erişilebilir olacak şekilde devam edebilmesi için kentsel mekânda ve ulaşım sistemlerinde birtakım düzenlemeler gerçekleştirilmiştir. Bu çalışmada Dünya'dan farklı örnekler incelenmiş; pandemi sürecinde kentsel hareketliliğe yönelik yapılan düzenlemeler ile ilgili literatür araştırılmış, hazırlanan raporlar ve medyada yer alan haberler derlenmiş, ayrıca alternatif ve yenilikçi ulaşım türlerinin yavaş da olsa değişmeye başlayan seyahat davranışlarındaki yerinin ortaya konulması amaçlanmıştır. Türkiye'den Ankara örneğinde irdelemenin yapıldı̆̆̆ çalışmada, pandemi boyunca yaşanan kriz durumunun Türkiye'deki kentler için de firsata çevrilebilmesi hedefiyle sonuç bölümünde sürdürülebilir kentsel hareketliliğin sağlanması için yerel yönetimleri de yakından ilgilendiren öneriler sunulmuştur.

Anahtar Kelimeler: COVID-19, pandemi, kentsel hareketlilik, seyahat davranışları, alternatif ve yenilikçi ulaşım türleri.

\footnotetext{
${ }^{1}$ Yüksek Lisans Öğrencisi, Yıldız Teknik Üniversitesi, Kentsel Mekân Organizasyonu ve Tasarım Programı. E-mail: nazserife.1@gmail.com ${ }^{2}$ Doç. Dr., Yıldız Teknik Üniversitesi, Şehir ve Bölge Planlama Bölümü. E-mail: chamamcioglu@gmail.com idealkent () Kent Araştırmaları Dergisi (Journal of Urban Studies) http://idealkentdergisi.com Geliş Tarihi Received Date: 30.09.2021 Kabul Tarihi Accepted Date: 26.12.2021
} 


\title{
Urban Mobility During the COVID-19 Pandemic: Examples of World and Experiences from Ankara
}

\author{
Şerife Özcan ${ }^{3}$ \\ ORCID: 0000-0003-3268-1528
}

\author{
Cenk Hamamcioğlu ${ }^{4}$ \\ ORCID: 0000-0002-3872-4608
}

\begin{abstract}
The COVID-19 pandemic, which was reported from Wuhan, has caused striking effects. With the effect of health concerns and habits have begun to reshape with the concept of physical distance and full lockdown. One of the reshaped situations is travel behavior and urban mobility. Among the changes can be seen the decrease in urban mobility, the fact that life is lived on a neighborhood scale, and that needs are generally met within walking distance or that public transportation is less preferred. Along with this process, some arrangements have been made in urban space and transportation systems so that mobility in different cities can continue in a healthy, safe and accessible way for everyone. In this article, different examples from the world were examined; the literature on the regulations made for urban mobility during the pandemic process was researched, the reports and the news were compiled, and it is also aimed to reveal the place of alternative and innovative transportation types. In the study, which examines the example of Ankara from Turkey, suggestions that are closely related to local governments are presented with the aim of turning the crisis experienced during the pandemic into an opportunity for the cities in Turkey.
\end{abstract}

Keywords: COVID-19, pandemic, urban mobility, travel behavior, alternative and innovative modes of transport.

\footnotetext{
${ }^{3}$ M.Sc Student, Yıldız Technical University, Urban Space Organization and Design Program. E-mail: nazserife.1@gmail.com

${ }^{4}$ Assoc. Prof., Y1ldız Technical University, Department of City and Regional Planning. E-mail: chamamcioglu@gmail.com

idealkent (c) Kent Araştırmaları Dergisi (Journal of Urban Studies)

http://idealkentdergisi.com

Geliş Tarihi Received Date: 30.09.2021 Kabul Tarihi Accepted Date: 26.12.2021
} 


\section{Giriş}

COVID-19 pandemi sürecinin başlaması ile, kentsel hareketlilikte ulaşım türlerinin tercih edilme ve kullanım değerinde değişimler meydana gelmiştir. Özellikle kapalı alanlarda kalma riski, insanlarla temasa geçme ihtimali ve fiziksel mesafe gibi konular ile toplu taşıma sistemlerinin kullanımı azalmıştır. Toplu taşıma aleyhinde gerçekleşen bu zorunlu tercih ve uyarılar sonucunda kentsel hareketlilikte özel otomobil kullanımının artmasının yanısıra yaya ve diğer bireysel ulaşım türleri de önem kazanmıştır. Örneğin, kentsel mekânda herkes için erişilebilir ve eşit ulaşım olanağı sağlamak amacıyla farklı ülkelerde bisiklet öncelikli ve e-scooter gibi mikro-hareketlilik kapsamında ele alınan alternatif ve yenilikçi sistemlere yönelik düzenlemeler hız kazanmıştır. Bir bakıma pandemi süreci; kentsel hareketliliğin dayanıklı, sürdürülebilir ve eşitlikçi olabilmesi için farklı duyusal, fiziksel ve mental özelliklere sahip insanı odağına alarak ve bütüncül bir ulaşım sistemi bakış açısıyla düşünülmesi gerekliliğinin altını çizmiştir. Bu bağlamda birçok ülkede, pandeminin yarattı̆ı krizi firsata çevirmek amacıyla, kentsel hareketlilikte yaya, bisiklet, e-scooter, paylaşımlı araç ve araç kiralama sistemleri geliştirilerek farklı mesafelerde, mümkün olduğunca özel otomobil kullanmadan erişimin sağlanması ve hareketliliğin arttırılması hedeflenmiştir.

Bu makalenin amacı, pandemi sürecinde kentsel hareketlilik deneyimlerini, değişen koşullar bağlamında yapılan düzenlemeleri, geliştirilen konseptleri Dünya'nın farklı kentlerinden örnekler ile açıklayarak Türkiye'deki kentlere ve yerel yönetimlere girdi sağlamaktır. Bu bağlamda kentsel hareketlilik ile ilgili olarak; pandemi sürecinde Türkiye'de yaşanan deneyimlerin ve karşılaşılan sorunların neler olduğunun, çözüm önerileri olarak hangi düzenleme ve uygulamaların yapıldığının ortaya konulabilmesi için örnek Ankara kenti seçilmiştir. Değerlendirme örneği olarak Ankara'nın seçilmesinde;

- büyükşehir ve başkent statüsünde olması, bu özellikleri ile pandemi sürecinde Türkiye'deki diğer kentlerin seyahat koşulları ve toplu taşıma bağlantılarında yaşanan sorunlar ve bu sorunların üstesinde gelme çabalarını ve düzeyini genel olarak yansıtma potansiyeli,

- ayrıca pandemi sürecinin ana yazar tarafından Ankara'da deneyimlenmiş olmasi

etkili olmuştur.

Bununla birlikte, çalışmada ele alınan pandemi süreci ile öne çıkan farklı kentlerden örnek uygulamaların Ankara kenti ve Türkiye'deki diğer kentle- 
rin toplu taşıma sistemlerinin işletimi ve bütünleşmesinin yanısıra mikro ölçekte hareketliliği etkileyen erişim sorunlarının çözümüne yönelik birtakım fikirler sunması katkı sağlayıcı görülmüştür.

Yukarıda açılanan amaç ve gerekçeler doğrultusunda bu çalışmada öncelikle literatür desteğinde kentsel hareketlilik kavramı ele alınmıştır. Daha sonraki bölümde pandemi süreci ve bundan kentsel hareketliliğin nasıl etkilendiğinin değerlendirilebilmesi için henüz literatürde kısıtlı sayıda pandemi deneyimlerini aktaran çalışmalara ve uluslararası kuruluşların raporlarına başvurulmuştur. Bu bağlamda öncelikle kentsel hareketlilikle ilgili olarak Dünya'dan dokuz ülkeye ait nicel tespit ve yorumları paylaşan -çok uluslu bir hizmet ağına sahip Ernst \& Young Global Limited firmasının hareketlilik bölümünden- Cardell ve Batra'nın Kasım 2020 tarihli çalışması dikkate alınmış, ardından iyi uygulama örnekleri ve geliştirilen konseptlerle ilgili Avrupa Birliği'nin ortak finansmanı ile desteklenen Avrupa Yenilik ve Teknoloji Enstitüsü'nün Kentsel Hareketlilik (EIT Urban Mobility) biriminin hazırladığı 2021 yılı tarihli “COVID-19 Pandemisi Sürecinde Kentsel Hareketlilik Stratejileri" raporundan yararlanılmıştır. Örnekler arasında kentsel hareketliliği geliştirmeye yönelik daha geniş bir perspektif sunan metropoliten ölçekli kentlerden Roma, orta-küçük ölçekli nüfusa sahip kentlerden de Tartu ve Lund kentleri tercih edilmiş, kriz durumuna cevap olarak gerçekleştirilen 'pop-up bisiklet yolları' ile daha uzun vadeli bir şehir planlama yaklaşımını içeren '15 dakikalık şehir' konseptleri kısaca açıklanmıştır. Bir sonraki bölümde ise Türkiye'den Ankara kenti ele alınmış, veri kısıtlllı̆ı̆ gözönüne alınarak kentsel hareketlilik ile ilgili Apple Hareketlilik ve Google Hareketlilik raporları ve Ankara Elektrik, Havagazı ve Otobüs İşletme Müessesesi (EGO)'nin Mart 2020-Eylül 2021 kentiçi günlük yolcu sayılarından yararlanılmiş, gözlem ve deneyimleme yöntemi ile de mevcut durum ve uygulamalar aktarılmıştır. Çalışmanın sonuç bölümünde, süreç boyunca yaşanan deneyimlerden ve uygulama örneklerinden yola çıkılarak, kriz durumunu fırsata çevirmek ve kentsel hareketliliği daha sürdürülebilir ve dayanıklı kılmak amacıyla, Avrupa Birliği'nin Kentsel Hareketlilik (EIT Urban Mobility, 2021) biriminin hazırladığı rapordan yapılan çıkarımların da ışığında, öneriler geliştirilmiştir.

\section{Kavramsal Çerçeve: Kentsel Hareketlilik}

Hareketlilik, kavram olarak ulaşım ile bağlantılı düşünüldüğünde, insanların ve yüklerin bir yere varması ya da bir hedefe ulaşması amacıyla yapılan eylemin mekândaki karşılı̆̆1 -yer değiştirme- olarak tanımlanabilir. 
Korkmazyürek ve Polat (2019) hareketliliğin temelinde, bulunulan konumun dışında istenilen başka bir konuma varmak olduğunu ifade etmektedir. Ancak kentsel hareketlilik insanların (bireysel, toplu olarak) ve yüklerin yalnızca A konumundan B konumuna ulaşmasının değil; kent içerisinde güvenli, hızlı, çevre dostu ve uygun fiyatlı bir şekilde dolaşımını, bireyler açısından ise gün içinde birden fazla farklı amaçlarla seyahat edebilmeyi, örneğin eğitime, kültüre, istihdama veya eğlenceye erişebilmeyi kapsamaktadır (Peralta-Quiros, 2015; Connective Cities, 2021). Bu sebeple Rodrigue (2020)'in de vurguladığı üzere kentsel hareketlilik, şehirlerin genel dinamikleri içinde karmaşık bir alandır. İnsanların ve yüklerin hareket etme şekillerinde birçok çapraz faktörün etkisi bulunduğundan kentlerde çekim gücü oluşturan arazi kullanımları, kent biçimi ve yaşam kalitesi kentsel hareketlilik ile yakından etkileşim içindedir (Camagni vd., 2002; Wee \& Handy, 2016; Meyer, Jan Hoekstra ve Westrik, 2020; EIT, 2021). Bu öz açıklamalar ışığında Alyavina vd. (2020), Georgakis vd. (2020) ile Shareen vd. (2020) ulaştırmayı; hareket etme sürecini veya bunu gerçekleştiren araçlar olarak tanımlarken, kentsel hareketliliği; seyahat taleplerinin (seyahatin miktarı ve tercih edilen ulaşım türü) sonucu ortaya çıkan bir kentin seyahat kapasitesi ile bunu iyileştirmenin yaratabileceği sonuçları ve fırsatları temsil ettiğinin altını çizmektedir.

Evrimleşen bir toplumda kentler sosyo-ekonomik açıdan değişerek gelişmekte, buna bağlı kentsel çevre de kaçınılmaz olarak değişime uğramaktadır. $\mathrm{Bu}$ durum, süreç içinde şehir planlamada yeni zorluklara neden olmakta ve kentsel hareketlilik ihtiyaçlarının güncellenmesini gerekli kılmaktadır. Konu ile ilişkili olarak Gakhenheimer (1999), Litman ve Burwell (2006), kent merkezlerindeki hızı ve plansız büyüme, artan özel otomobil sayısı ve ulaşım sistemlerinin doğru planlanmaması sonucunda hareketliliğin giderek bozulduğundan ve çevre sorunlarına yol açtığından bahsetmektedir. Günümüzde ise hem teknolojik gelişmeler hem de insanların seyahat davranışlarını değiştirmeye aday olan sürdürülebilir hareketlilik paradigmasında; (1) fosil enerji tüketiminin azaltılması ve (2) işler bir ulaşım sisteminin (kentsel, lojistik, bireysel - paylaşımlı ulaşım ve hareketlilik) oluşturulması için (3) kullanıcı odaklı bütünsel bir hizmet sunacak seyahat talep yönetiminin (örneğin; MaaS - Mobility as a service / Bir Hizmet Olarak Hareketlilik) ve sürdürülebilir kentsel hareketlilik planlarının (SUMPs) önemi vurgulanmaya başlamıştır (May, 2015; Matyas ve Kamargianni, 2017; Macharis ve Keseru, 2018). Çalışmasında kentsel hareketliliğin evrimini ele alan Jones (2014) ve Karahan Kamacı (2021), kavramı 5N1K (ne, neden, nasıl, ne ile, nerede, kim ya da kim tarafından) çerçevesinde açıklamaktadırlar; 
$N e$ ? Kentsel hareketlilik, günlük gerçekleşen yolculukların tamamı ve bu yolculuklar ile ilgili yöntem ve koşullar (seçilen ulaşım türleri, yolculuğun uzunluğu, yolculuk boyunca harcanan zaman vd.) şeklinde tanımlanmaktadır (Costa vd., 2017; IGI Global, 2021). Aynı zamanda kentsel hareketlilik fiziksel hareketliliğin bir parçası olmakla birlikte sosyal hareketlilikten etkilenen ve onu etkileyen, mekânda yapılan yer değiştirme durumu anlamina gelmektedir.

Neden? Kentsel hareketliliği oluşturan talepler arasında, öncelikle insanların bulundukları konumlardan gereksinim ve ihtiyaçlarını karşılayamaması ve sonucunda seyahat talebi oluşturması gelmektedir. Aynı zamanda insanın sosyal bir varlık olması ve hareketliliğin de bu sosyallikten beslenmesi iletişim kurmayı da kolaylaştırmaktadır. Ayrıca kentsel mekânın arazi kullanım yapısı da seyahat etme talebi oluşturduğundan kentsel hareketliliği etkilemektedir. Bu bağlamda günlük ihtiyaçların dışında donatı ve hizmet alanlarına ulaşmak amacı da kentsel hareketliliği oluşturan bileşenlerdendir.

Nasıl? Kentsel hareketlilik, kullanımı ölçekler arası değişen ulaşım türlerini gerektirmektedir. Kısa mesafeli yolculuklarda yürüme, bisiklet, escooter gibi ulaşım türleri mikro ölçekte hareketliliği oluşturmaktadır. Daha uzun mesafeler için ise otobüs, raylı sistemler, özel araç gibi daha hızlı ve kısa sürede uzun mesafeleri katedebilen ulaşım araçları kentsel hareketliliği desteklemektedir. Aynı zamanda hareketliliğin sağlanabilmesi ve araçların hareket edebilmesi için kentsel mekânda farklı hareket yüzeylerine, açıkapalı duraklama noktalarına, yapılara, yollara ihtiyaç duyulmaktadır.

Ne ile? Hareketlilik, yaya olarak gerçekleştirildiği gibi mikro hareketlilik kapsamına giren bisiklet, scooter gibi araçlarla da gerçekleştirilebilmektedir. Motosiklet, otomobil gibi motorlu taşıtlar hareketliliğin daha uzun mesafelerde sağlandığı vasıtalardır. Toplu taşıma ise hareketliliğin kitlesel sağlandığı sistemlerden biridir. Toplu taşıma kapsamında ara toplu taşıma (para transit) olarak tanımlanan dolmuş, minibüs gibi araçlar yer alırken kamusal toplu taşıma (public transit) olarak tanımlanan otobüs, metrobüs, troleybüs gibi lastik tekerlekli, tramvay ve metro gibi raylı, feribot, vapur gibi su yüzeyinde hareket eden araçlar da bulunmaktadır.

Nerede? Hareketlilik, kentsel mekânda ilişkileri kurarak temas ve bağlantı sağlar. Dolayısıyla bu bağlantılar yerleşim alanları arasında olabildiği gibi konut, donatı ve temel hizmet alanlarına erişim için harcanan çaba da kentsel hareketliliğin kapsamındadır. 
Kim ya da kim tarafindan? Kentsel hareketliliği oluşturan unsurlar, her koşuldaki bireylerin özellikleri kapsamında değerlendirilmelidir ve buna göre hareketliliğin kapsamı belirlenmelidir (Karahan, 2021). Dolayısıyla hareketliliği sağlayan unsurların demografik, ekonomik ve sosyal özellikleri önemli hale gelmektedir. Kentsel hareketlilik ancak bu özelliklere göre planlandığında kapsayıcı ve katılımcı bir deneyim haline gelebilmektedir. Bu bağlamda kentsel hareketliliğin stratejileri ise şu şekilde sıralanmaktadır (Leo vd., 2017, PEARL, 2015):

- Kentsel hareketliliğin sağlanması için gereken kaynaklar ekonomik olarak verimli, ekoloji odaklı, sürdürülebilir olmasının yanında sosyal açıdan da kapsayıcı politikalar üretilmelidir.

-Kentsel hareketlilik planları, kent bütününe entegre ve sürdürülebilir olacak şekilde yapılmalı ve yerel yönetimler tarafından uygulama stratejileri benimsenmelidir.

- Hareketlilik, bireysel değil kitlesel ulaşım stratejini benimsemelidir. Böylece yolculuk talebi yönetilmelidir.

-Yayalar, bisiklet ve e-scooter gibi mikro ölçekte hareketliliği sağlayan araçlar için yönetmelikler hazırlanmalı ve altyapı iyileştirilmelidir. Bu bağlamda kentsel tasarımın bileşenlerinden biri de ulaşımdır. Dolayısıyla kapsayıcı, herkes tarafından erişilebilir ve güvenli, sürdürülebilir, sağlıklı bir kentsel hareketlilik ve ulaşım sistemlerinin kentsel mekân ile bütünleşmesini sağlamak mekân organizasyonu ve tasarım disiplinin görevlerinden biridir.

- Hareketliliğe dair farkındalığı oluşturmak amaciyla bilginin yayılması için yapılan kampanyaların yanısıra kent sakinlerinin katılımının sağlandığı bir planlama süreci izlenmelidir.

\section{Pandemi Sürecinde Kentsel Hareketlilik}

COVID-19 pandemi sürecinin başlamasıyla birlikte değişen koşullar günlük hayatın dinamiğini de değiştirmiştir. Değişen bu dinamiklerden biri de hareketliliktir. Tam kapanma ile birlikte gerek sosyal gerekse fiziksel mesafe, izole olma gibi kavramların gündeme gelmesiyle mekânların ve ulaşım sistemlerinin kullanımı birtakım değişimlere uğramış, ancak daha sonrasında gündeme gelen yeni normal gibi süreçler kentlerde ulaşım sistemlerindeki tercih ve davranış biçimlerine bağlı olarak hareketliliğin yeniden şekillenmesine yol açmıştır. 
Pandeminin ilk aşaması olan kapanma sürecinde evden çalışma, e-alışveriş ya da uzaktan eğitim gibi uygulamalar ile kamusal etkinliklerin ve hareketliliğin azaldığı ulaşıma ve toplu taşıma araçlarına olan talebin düşüşe geçtiği bir dönemin yaşanmasına neden olmuştur (De Vos, 2020). Bu süreçle ilgili olarak Cardell ve Batra (2020)'nın bulgularına göre Avrupa, Kuzey Amerika ve bazı Asya ülkelerinden olmak üzere toplam dokuz ülkeyi kapsayan araştırmaya göre iş seyahatleri bağlamında 2 saat ve üzeri sürede yapılan yolculuklar \%94 oranında azalmıştır (Şekil-1). Aynı zamanda 1-2 saat zaman aralığında yapılan yolculuklar \%85 azalırken 30 dakika-1 saat arasında gerçekleşen yolculuklar \%73 azalmıştır. Boş zaman ya da eğlence için yapılan aktiviteler ise genellikle 30 dakika üzerinde en az \%54 oranla azalmaya başlarken 30 dakika altında yapılan yolculuklar \%79 oranında artmıştır (Şekil-2). Bunun sebebi ise tam kapanma sürecinde market, eczane gibi gündelik ihtiyaçların en kısa mesafelerden karşılanması olmuştur.

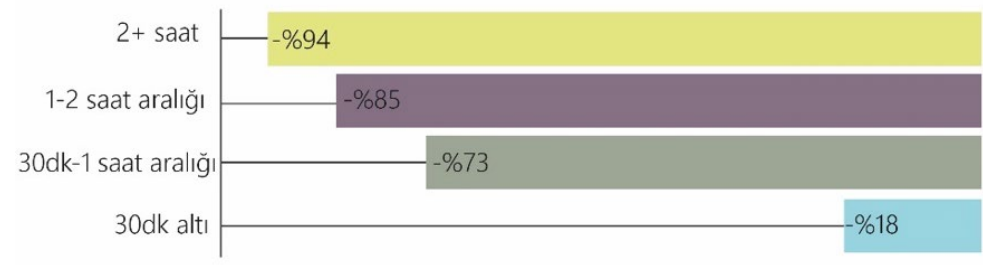

Şekil 1. Dünya genelinde bulunan ülkelerde iş kapsamında yapılan yolculukların COVID-19 pandemi süreci ile değişimi. Ülkeler: Almanya, ABD, Çin, Güney Kore, Hindistan, İngiltere, İtalya, İsveç, Singapur. (Cardell, M., Batra, G., 2020)

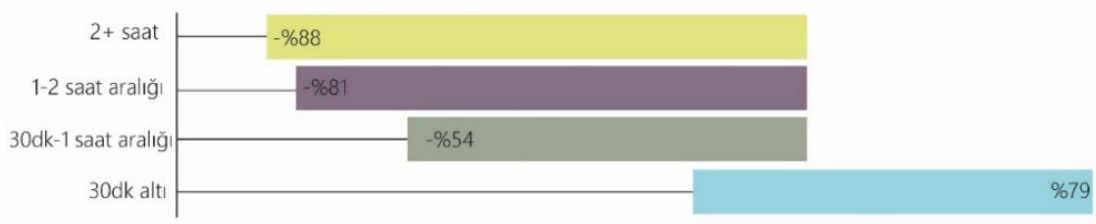

Şekil 2. Dünya genelinde bulunan ülkelerde boş zaman ve eğlence kapsamında yapılan yolculukların COVID-19 pandemi süreci ile değişimi. Ülkeler: Almanya, ABD, Çin, Güney Kore, Hindistan, İngiltere, İtalya, İsveç, Singapur. (Cardell, M., Batra, G., 2020)

Bu sürecin olumlu yanlarından biri olarak şekil-3'teki Cardell ve Batra (2020)'nın bulgularına göre iş seyahatlerine bağlı hareketliliğin azalmasıyla birlikte karbon emisyon oranı da \%56 azalmıştır. Boş zaman ve eğlence aktiviteleri bağlamında yapılan yolculukların azalması ya da sürelerinin kısıtlanması sonucunda ise karbon emisyon oranı \%62 azalmış ve dolayısıyla karbon salımında etkili olan ulaşım taşıtları (özellikle özel otomobiller) ve bu taşıtlar 
kaynaklı trafik yoğunluğu ile uzun süreli dur-kalk ve beklemelerin azalması, bir bakıma, sürdürülebilirlik ve iklim krizine karşı benimsenen ilkeleri desteklemiştir.

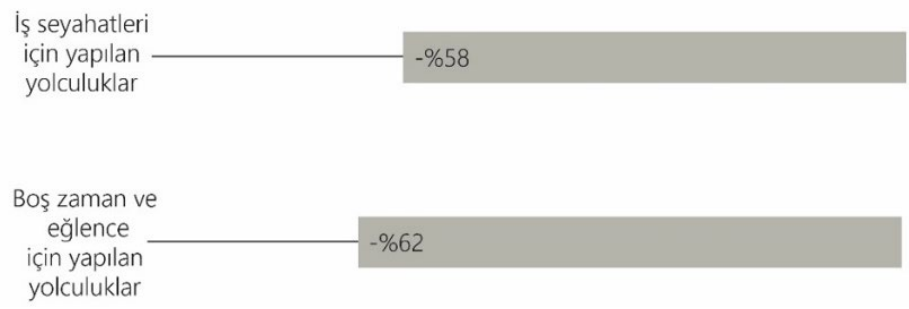

Şekil 3. Dünya genelinde bulunan ülkelerde COVID-19 süreci sonrası değişen ulaşım talebi ile karbon emisyon oranlarındaki değişim. Ülkeler: Almanya, Amerika, Çin, Güney

Kore, Hindistan, İngiltere, İtalya, İsveç, Singapur. (Cardell, M., Batra, G., 2020)

Öte yandan sokağa çlkma yasaklarıyla birlikte boş kalan sokaklar, caddeler trafik gürültüsünün ve kirliliğinin olmadığı kanal mekânlara bürünmüşlerdir. Süreç başlangıcında birçok insan evinde kalsa da evden çalışma imkânı olmayanlar için toplu taşıma sistemlerinde yeni kurallar geliştirilmiştir. Ancak süreç ilerledikçe, normale dönüş stratejileri ile bu toplu taşıma sistemlerinde kullanıcı sayılarının artması ve fiziksel mesafenin korunamaması sağlık açısından endişelerin oluştuğu, tedirgin olunan seyahatler meydana getirmiştir. Bu nedenle de birçok insan, pandemi öncesinden de daha yüksek oranda, özel araç kullanarak ulaşım ihtiyaçlarını sağlamaya çalışmıştır. Ayrıca araç kiralama ve paylaşımlı otomobil kullanımının da arttı̆̆ gözlemlenmiş, bununla birlikte birçok kentte bisiklet ve scooter sistemleri de yaygınlaşmiştır.

Evde kalan, uzaktan çalışan ve eğitim alan kişiler için ise hayat mahalle ölçeğine dönüşmüştür. Günlük ihtiyaçların birçoğu yakın mesafedeki market, eczane ve açık hava aktivitelerinin gerçekleştirildiği park, çocuk parkı, koşu ve yürüyüş alanları gibi yerlerden karşılanmaya çalışılmıştır. Bu koşullar mahalle ölçeğinde yürüme mesafesinde erişilebilecek kentsel hizmetlerin de ne kadar önemli olduğunu göstermiş ve hareketliliğin devam edebilmesi amaciyla alternatif çözümler üretilmiştir. Pek çok kentte bu amaçla belediyeler ve özel firmalar ortaklıkları ile üretilen çözümlerin ortak ilkesi ise yaya ve bisikletli için sokak ve cadde enkesitlerinde daha çok alan ayrilarak güzergâh düzenlemelerinin gerçekleştirilmesi ve mikro hareketlilik ölçeğinde daha fazla imkân sağlanması olmuştur. 
Özellikle Avrupa ülkelerinde 2020 yaz ayları ile pandemi sürecinin etkileri devam ederken birçok insan toplu taşıma araçlarından uzak durarak bisiklet ulaşımına yönlenmiş, böylece hem fiziksel mesafe korunmaya hem de eylemlere erişim olanağ ile hareketlilik güçlü tutulmaya çalışılmıştır (Çörek Öztaş, 2020). Dünya Sağlık Örgütü tarafından da desteklenen yaya ve bisiklet ile ulaşımın önemine bir kez daha dikkat çekilmiştir.

Kent sakinlerinin pandemi nedeniyle toplu taşımaya karşı mesafeli durmaları, bisiklet yollarına olan gerekliliği arttırmakla birlikte kullanımlarını da desteklediğinden pek çok şehir, hızlı bir şekilde uygulanan ve çoğu geçici olarak tanımlanan, genellikle doku değişikliği ya da işaretler ile mekânda minimum müdahale sonucu oluşan "pop-up" bisiklet yollarını inşa etmeye başlamıştır.

\section{Pandemi Sürecinde İyi Uygulama Örnekleri ve Geliştirilen Konseptler}

Bu bölümde, bir önceki bölümde açılanan, pandemi sürecinde kentsel hareketlilikte yaşanan değişim ve saptamalar doğrultusunda farklı ülkelerde gerçekleştirilen ve 'iyi uygulamalar' olarak nitelendirilen örneklere ve konseptlere yer verilmiştir. Pandemi ile değişmek durumunda kalan seyahat davranışları ve kentsel hareketlilik bağlamında salgının yarattığ çevirmek büyük oranda yerel yönetimlerce alınan kararlar ve kentsel mekânların olanakları dahilinde mümkün olabilmiştir. Bu bağlamda bazı ülkelerde yaya ve bisiklet odaklı hareketliliğe imkân veren ulaşım sistemleri planlamıştır. Genellikle Avrupa ve Kuzey Amerika'da görülen ve “bisiklet devrimi" olarak adlandırılan bu süreç, sokak işlevlerinin de değişmesine sebep olmuştur. Özellikle San Francisco, Paris, Barcelona, New York, Toronto gibi birçok şehir sokaklarını araç trafiğine kısmen kapatarak "paylaşımlı sokaklar" uygulamasını yaygınlaştırmıştır. Yol kenarı otopark alanlarının çoğu yeme-içme işletmelerinin kullanımına sunularak daha geniş alanlarda, insanların fiziksel mesafelerini korumaları sağlanarak hizmet vermeleri mümkün kılınmış ve bu durum sokağın kullanımının yeniden düşünüldüğü bir sürece doğru evirilmiştir (Çörek Öztaş, 2020).

Chicago, Los Angeles, Oakland, San Francisco ve Seattle gibi bazı Kuzey Amerika kentlerinde "yavaş sokaklar" ve "açık sokaklar" uygulamaları benimsenerek birçok ana cadde ve bağlantılı sokak kısmen veya tamamen araç trafiğine kapatılarak yürüme ve bisiklet kullanımına ağırlık verilmiştir. Bu kanal mekânlarda bireysel ve paylaşımlı scooter sistemlerinin de kullanılabilirliğinin sağlanması ile kentsel hareketlilik bağlamında verimlilik bir 
ölçüde iyileştirilmiştir. Viyana ise "ferah sokaklar" ilkesini benimseyerek 18 sokağı araç trafiğine kapatmış yaya odaklı hareketlilik sağlamıştır. Tüm bu uygulamalar insanı odağına alırken yaşlı, çocuk, farklı duyusal, fiziksel veya mental özelliklerdeki bireyler de dahil olmak üzere herkesin, fiziksel mesafeyi koruyarak, erişilebilirliği geliştirilmeye çalışılmıştır (Erturan, 2020).

Pandemi süreci, sokağın yalnızca bağlantı amaçlı kanal bir mekân olmadığını, aynı zamanda sosyal ilişkilerin de sürdürüldüğü bir yaşam alanı olduğunu da göstermiştir. Ulusal Şehir Ulaştırma Yetkilileri Birliği (NACTO - The National Association of City Transportation Officials) ve Küresel Şehirlerin Tasarlanması Girişimi (Global Designing Cities Initiative) iş birliğinde sokağın kullanımı üzerine çalışmalar yürütülmüş, alternatiflerin sunulduğu bir rehber yayınlanmıştır. Bu rehberde şekil-4'te de görüldüğü üzere paylaşımlı sokaklar çeşitli işlevlerde kullanılan kamusal mekânlar olarak ele alınmıştır. Bu işlevler arasında yürüme, yeme-içme, sağlık ve alışveriş gibi ihtiyaçların karşılanabilmesinin önemi vurgulanmış, çeşitli işlevler arasında oyun, yükleme işlemleri ve iletişim gibi eylemler yer almıştır.

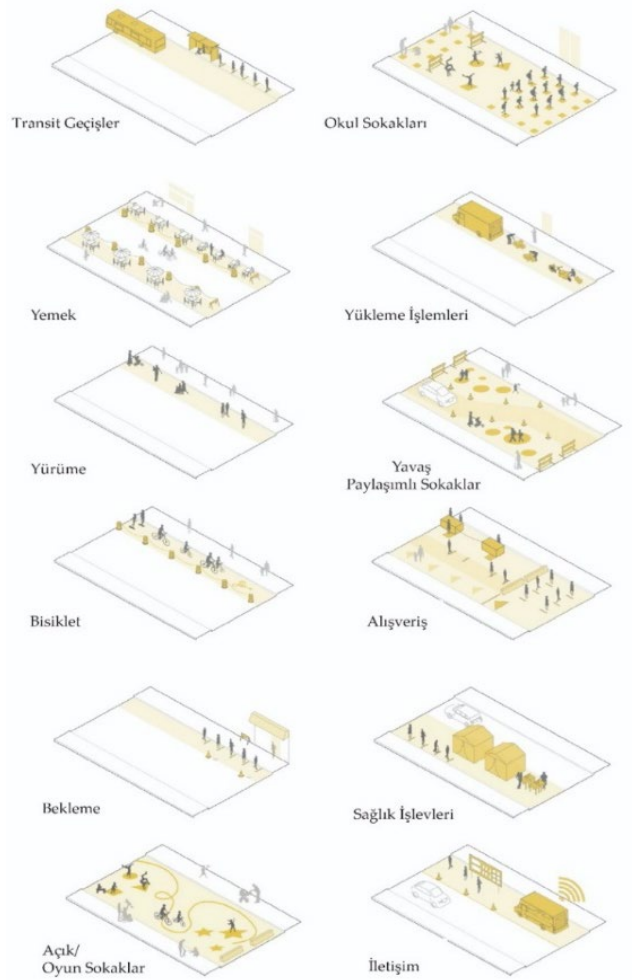

Şekil 4. Sokak Kullanım Çeşitliliği (National Association of City Transportation Officials, 2020). 


\section{İyi Uygulama Örnekleri}

Çalışmanın bu bölümünde Avrupa'dan iyi uygulama örnekleri incelenmiştir. Bunun için Avrupa genelinde kentsel hareketlilik alanında çalışmalarda bulunan ve araştırmaları destekleyen Avrupa Birliği'nin Yenilik ve Teknoloji Enstitüsü'ne bağlı Kentsel Hareketlilik (EIT Urban Mobility) biriminin hazırladığ1 “COVID-19 Pandemi Sürecinde Kentsel Hareketlilik Stratejileri” raporundan yararlanılarak İtalya' dan Roma, Estonya' dan Tartu ve İsveç'ten Lund olmak üzere üç örnek kent belirlenmiş, pandemi sürecinde kentsel hareketliliğin sağlıklı bir şekilde yönetildiği, birbirinden farklı ve "iyi” olarak nitelendirilen uygulamalar derlenmeye çalışılmıştır. Biri büyük (Roma), diğer ikisi (Tartu ve Lund) orta-küçük ölçekte büyüklüğe sahip bu üç kentin örnek olarak seçilmesinde, yenilikçi ve alternatif ulaşım araçlarını temel almalarının yanında kriz durumunda insan odaklı ve herkes tarafından erişilebilir ulaşım stratejilerini benimsemeleri etkili olmuştur. Ayrıca bu bölümde Dünya'nın farklı şehirlerinden örnekler desteğinde "pop-up bisiklet yolları" ve "15 dakikalık şehir" konseptlerine de yer verilerek bir sonraki bölümde ele alınan Türkiye'den Ankara kenti deneyimleri ile kıyaslama ve çıarımlarda bulunmak amaçlanmıştır.

\section{- Roma, İtalya}

Avrupa Birliği içerisinde en kalabalık ilk on şehir arasında bulunan İtalya'nın başkenti Roma, yaklaşık olarak 3 milyon nüfusa sahiptir. Radyal yol ağına sahip olan kent, şekil-5’te görüldügüü üzere yoğun trafikle mücadele etmekte, yüksek otomobil ve motosiklet bağımlılığının yol açtığı hava kirliliğinin de üstesinden gelmeye çalışmaktadır.

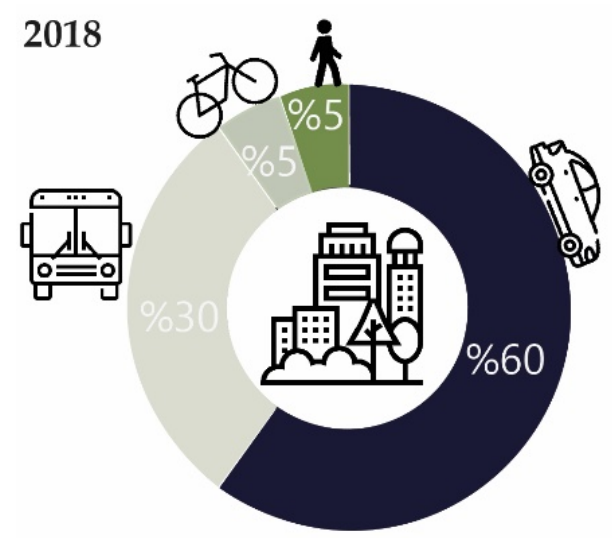

Şekil 5. Pandemi öncesi, Roma kentinde 2018 yılında ulaşımın türel dağılımı (EIT Urban Mobility, 2021). 
Roma kentinin karşılaştığı bu zorlukları aşmak amacıyla onaylanmış iki aktif hareketlilik planı bulunmaktadır. Bunlardan ilki Sürdürülebilir Kentsel Hareketlilik Planı (SUMP- Sustainable Urban Mobility Plan) 2018, diğeri ise önümüzdeki üç yılı kapsayan Elektrikli Hareketlilik Planı'dır. Pandemi sürecinin başlamasıyla birlikte onaylanan bu planlarla hareketliliği verimli kılmak amaciyla stratejiler benimsenmiştir (EIT, 2021). Bunlar arasında öne çıkan üç strateji şunlardır:

Strateji 1: Metro ve otobüs araçlarında yolcu kapasitesinin azaltılması

Roma'da ilk sokağa çıkma yasağının sona erdiği 2020 Nisan ayında toplu taşıma yeniden kullanılmaya başlanmıştır. Ancak sağlık kurallarına uygun bir yolculuğu teşvik etmek amaciyla otobüs ve metrolarda yolcu kapasitesinin üçte iki oranında azaltılması benimsenmiş, bazı koltuklar hizmet dışı bırakılmıştır (Şekil-6).

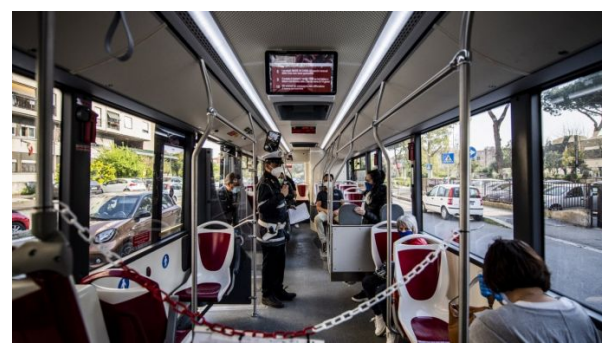

Şekil 6. Roma'da kısıtlanan toplu taşıma koltukları

(Coronavirus: Rome public transport in Phase Two (2020, 1 Mayıs).

Bu uygulamalara yönelik ana hedef kentsel mekânda insan sağlığını korumak ve toplu taşıma hizmetini güvenli hale getirmek amaç olarak benimsenmiştir. Aynı zamanda otobüs şoförlerinin de gözetimiyle en çok kullanıcılar arası fiziksel mesafeye uyulan araçların otobüsler olduğu belirlenmiştir.

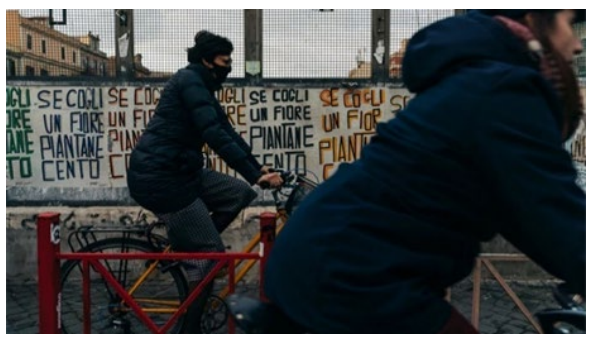

Şekil 7. Roma'da bisiklet kullanımı

(Marino, G.C., 2020) 


\section{Strateji 2: Mikro hareketliliği teşvik etmek}

Roma, genelinde 350.000 motosiklet sahipliğiyle mikro hareketliliğin hâkim olduğu bir kent olmakla birlikte COVID-19 pandemi süreci öncesi onaylanan Elektrikli Hareketlilik Planı kapsamında paylaşımlı motosiklet, elektrikli scooter ve bisiklet gibi sistemlerin kullanımını artırmak için ücret indirimleri uygulanmıştır (Şekil-7).

\section{Strateji 3: Kent genelinde elektrikli araçlar için şarj istasyonları altyapısının} oluşturulması

Elektrikli Hareketlilik Planı kapsamında şarj istasyon kapasitesinin arttırılmasına yönelik stratejiler uygulamıştır. 2020 yılında, planlanan şarj istasyonlarından 750'si hayata geçirilmiştir (Şekil-8). Şarj istasyonları konumlarının belirlenmesi amaciyla kamuoyunu bilinçlendirme ve katılım platformu oluşturulmuştur. Platform üzerinden kent sakileri, şarj noktaları için üç konum belirlemiş olup sonrasında nihai konumlar için de halkın tercihleri dikkate alınmıştır.

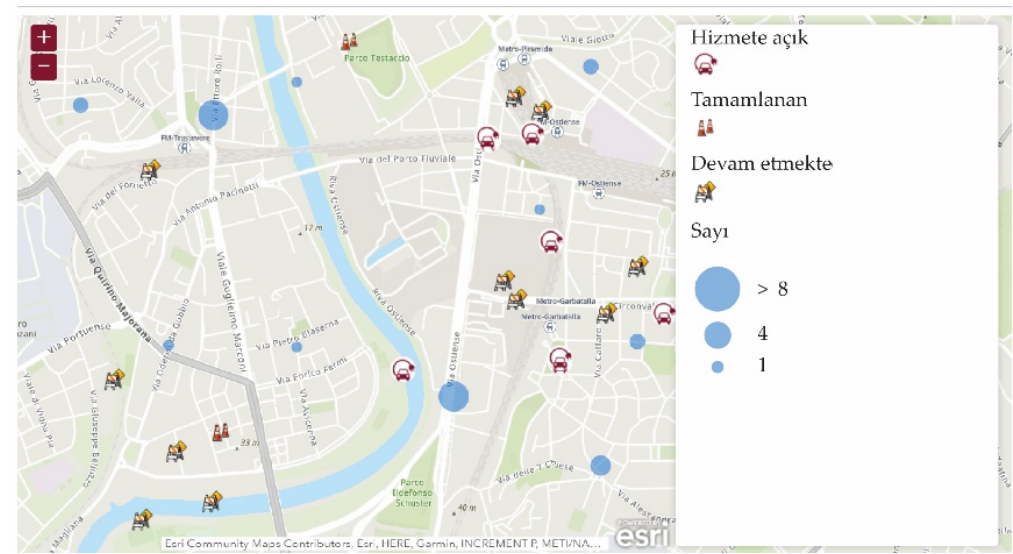

Şekil 8. Roma'da mevcut durumda şarj istasyonlarının konumu

(Mobilità elettrica, 2021, 29 Eylül).

\section{- Lund, İsveç}

İsveç'in en hızlı büyüyen kentlerinden biri olan Lund, 91.940 nüfusu ile (Avrupa İstatistik Ofisi, 2018) bir sanayi ve iş merkezidir. Bu sebeple ülke çapında işgücünü çekmekle birlikte yüksek erişilebilirlik ve sürdürülebilir ulaşımın da dikkate alındığı bir kenttir. Şekil-9'da kentin 2018 yılındaki ulaşım alışkanlıkları görülmektedir. Kentin ulaşım hedeflerinin temelini ise Lund Master Planı ve bu planın LundaMaTs III isimli sürdürülebilir yolculuk stratejileri oluşturmaktadır. 


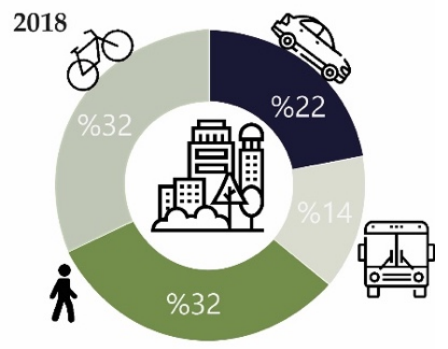

Şekil 9. Pandemi öncesi, Lund kentinde 2018 yılında ulaşımın türel dağılımı (EIT Urban Mobility, 2021).

Araç bağımlılı̆̆ının, mücadele edilen problemlerden biri olarak vurgulandığı EIT (2021) raporunda Lund kenti ile ilgili öne çıkan iki strateji şu şekilde açılanmaktadır:

Strateji 1: Güvenli bisiklet yollarn (fall-friendly cycling path)

COVID-19 pandemi süreci öncesinde de yoğun olarak kullanulan bisiklet yolları, kötü sokak döşemelerinden dolayı birçok kazaya şahit olmuştur. Bu sebeple hedeflerden biri, yolları "güvenli yol" olacak şekilde düzenlemek ve yaralanma risklerini azaltmak olmuştur (Şekil-10). Benimsenen bu konsept ile bisiklet sürmek için sert, ancak düşme durumunda korunmak amacıyla yumuşak bir malzeme ve doku tercih edilerek COVID-19 pandemi sürecinde de bisiklet kullanımı teşvik edilmiştir.

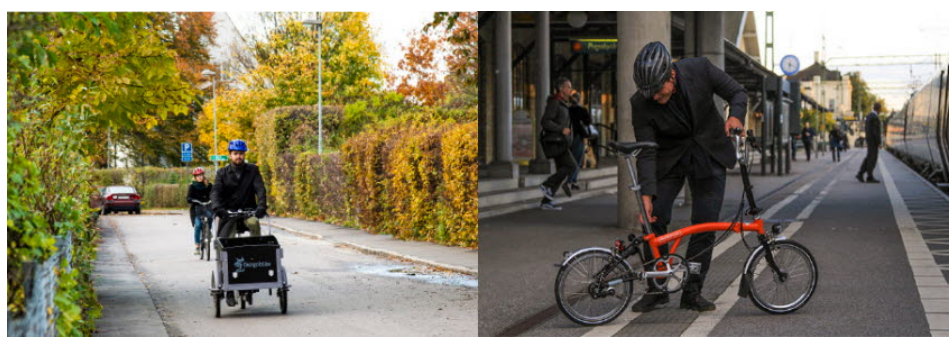

Şekil 10. Lund kenti, bisiklet yolları ve kullanımı

(Cycling in Lund, 2020, 23 Ekim).

Strateji 2: Okullarn etrafinda "yaşayan sokaklar"

İsveç, toplumun fiziksel ve ruh sağlığı gerekçesiyle tam kapanma süreci yaşamamıştır. Bu süreçte eğitim yüz yüze devam etmiştir (BBC, 2020). "Yaşayan sokaklar" konseptinin benimsendiği bu uygulamanın amacl, sokağın çok amaçlı yönünü öne çıkarmak ve okulların etrafinda araç yoğunluğu so- 
nucu oluşan trafiği azaltmak olmuştur. Öncelikle bir pilot proje olarak başlayıp geçici bir süre test edilmiştir. Bir hafta boyunca, çeşitli okulların çevresindeki yollar araç trafiğine kapatılmış ve eğitimin bir parçası olarak eğlence amaçı kullanılmıştır. Avrupa Hareketlilik Haftası'nın bir parçası olarak başlayan proje, çocukları ve velilerini yürüyerek ve bisiklet ile hareket etmeye teşvik etmiştir.

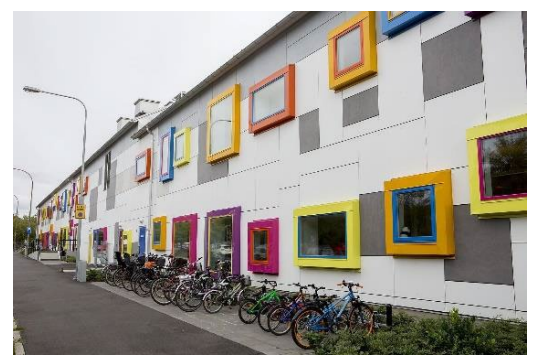

Şekil 11. Lund kentinde "yaşayan sokak" konseptinden bir örnek (EIT Urban Mobility, 2021).

\section{- Tartu, Estonya}

Tartu, 93.124 nüfusu ile (Estonya İstatistik Kurumu, 2017) Estonya'nın ikinci büyük kentidir ve yaklaşık \%36'sı öğrenci olan bir nüfusa sahiptir (Tartu, 2019). 2018 yılından beri kent, ulaşım altyapısını katılımcı süreçler ile yenilikçi çözümler dahilinde geliştirmektedir. Şekil-12'de 2019 yılındaki ulaşım alışkanlıkları verilen kentin hareketlilik stratejileri kapsamında araç bağımlılığını azaltmak için yaya bölgelerinin iyileştirilmesi ve toplu taşımanın teşvik edilmesi hedeflenmiştir. Aynı zamanda sürdürülebilirlik kapsamında Ocak 2020'den beri toplu taşıma sistemleri düşük emisyonlu ve yenilenebilir enerji kullanılarak işletilmektedir.

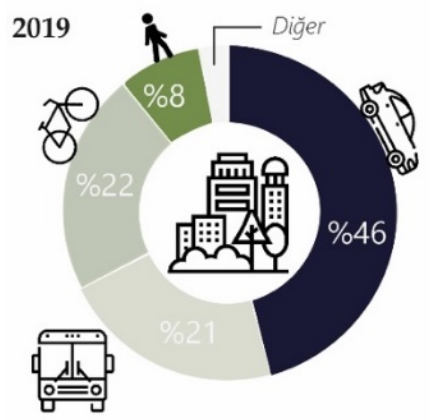

Şekil 12. Tartu kentinde 2019 yılında ulaşımın türel dağılımı

(EIT Urban Mobility, 2021). 
Tartu ile ilgili olarak EIT (2021) raporunda bahsedilen üç önemli strateji şunlar olmuştur:

\section{Strateji 1: Akillı bisiklet paylaşımı}

Haziran 2019'da kent genelinde 500 e-scooter, 250 bisiklet ve 69 bisiklet paylaşım istasyonu ile bisiklet paylaşım sistemleri uygulamaya konulmuştur (Şekil-13). Proje kapsamında kullanılan slogan "15 Dakikadan Az Her Yerde" olmuştur. Her ne kadar soğuk iklim koşullarının hâkim olduğu coğrafyada yer alsa da projenin genel vizyonu bisiklet ve yürümenin teşvik edilmesidir. Bunda özellikle COVID-19 pandemi sürecinde paylaşımlı sistemlerin uygulamaya geçmiş olması da rol oynamıştır. Projenin kentle olan entegrasyonu ve belirli bir başarıya ulaşılmasında paylaşımlı bisiklet sistemlerinin yaya akışınn yüksek olduğu ve otobüslere erişimin daha az olduğu bölgelerde uygulanması etkili olmuştur.

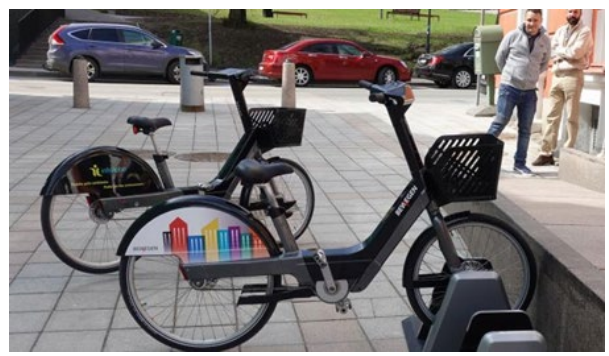

Şekil 13. Tartu kentinde paylaşımlı bisiklet sistemleri

(Bicycles for Tartu's bicycle sharing system coming from Canada (2021, 18 Mart).

\section{Strateji 2: Otobüs ă̆larmmn dönüştürülmesi}

Tartu'da günlük kent içi yolculuklarda özel otomobil kullanımının azaltılması amacıyla, mevcut otobüs ağında bazı değişikliklere gidilmiştir. Otobüs ağında, kısa mesafelerde sık aralıklı seferler düzenlenirken otobüs hatları arasında da daha işlevsel bağlantılar kurulmuştur. Aynı zamanda düşük emisyonlu otobüslerin de hizmete başlaması, rotaların belirlenmesi için kent sakinleri ile katılımcı bir sürecin yönetilmesi, temassız ödeme gibi sistemlerle de yenilikçi ulaşım hizmetlerinin gelişimi devam etmiştir.

\section{Strateji 3: Araçsız caddeler}

COVID-19 pandemi sürecinde hareketlilik kapsamında başarılı uygulamalar arasında gösterilen Vabaduse Bulvarı (Şekil-14), 2020 yılı Temmuz ayı boyunca trafiğe kapalı bir caddeye dönüştürülmüştür. Proje, yalnızca sosyal mesafe için olanak sağlamakla kalmayıp; kurulan pazarlar, seyyar yiyecekiçecek, açık hava sineması gibi işletmelerle de ekonomik bir katkı sağlamıştır. 
Wang (2020), caddenin trafiğe kapanmasıyla birlikte caddeye, ilk üç günde 18.000 ziyaretçi ağırladığını belirtmektedir. Proje, pilot olarak uygulanmış olup bir farkındalık kampanyası da oluşturarak sosyal etkileşimi de arttırmıştir.

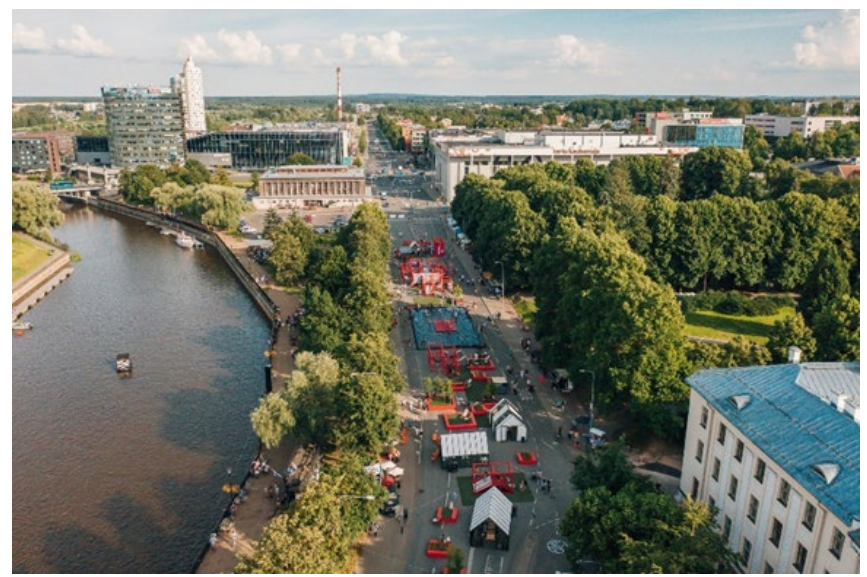

Şekil 14. Vabaduse Bulvarı'ndan yaya aktiviteleri-Temmuz, 2020 (Estonya'da Bir Ana Cadde Arabalardan Arındırıldı, 2020, 7 Ekim).

\section{Pop-up Bisiklet Yollan}

Salgının yaratmış olduğu pandemi krizi kent içi ulaşım açısından firsata çevirme yöntemlerinden biri de bisikletin bir ulaşım aracı olarak benimsenmesi ve yaygınlaştırılması olmuştur. Bisiklet kullanımın yaygınlaştırılması ve teşvik edilmesi günlük hayatın işleyişini oldukça etkilemiştir ve bu durumun etkilerinin pandemi süreci sonrası da devam edeceği öngörülmektedir.

Bu süreçte Meksika, Milano, Berlin, Barselona, Seattle, Roma gibi birçok şehirde "pop-up" bisiklet yolları düzenlenmiştir. Ayrıca;

- Bogota, otomobil trafiğinin hâkim olduğu birçok aksta şeritlerden birini bisiklet yoluna ayırarak kent genelinde 76 kilometrelik bisiklet yolu oluşturmuştur. Uygulama sonrası kent içi toplam bisiklet yolu ağı 626 kilometreye ulaşmıştır. Aynı zamanda herkesin erişiminin yaya olarak sağlanabilmesi amaciyla 120 kilometre uzunluğunda yol ağ1 motorsuz ulaşıma açılmıştır (NACTO, 2020).

- Milano ve Seattle'da yaklaşık 35 kilometre uzunluğunda yol ağı yaya ve bisiklet kullanımına ayırmıştır. Bunların çoğu pop-up olarak nitelendirilse de pandemi öncesinde ana alışveriş caddelerini yaklaşık olarak bin 
bisikletli kullanırken, süreç içerisinde bu değer ortalama olarak yedi bin bisikletliye kadar çıkmıştır (Çörek Öztaş, 2020) (Şekil-15).

-Brüksel, tüm kent merkezini yaya ve bisikletliler için düzenleyerek araç trafiğini sınırlamıştır. Ayrıca kent merkezinde araç ile ulaşılan sokaklarda araçlara hız limiti getirerek yaya öncelikli uygulamaları benimsemiştir (NACTO, 2020).

- Paris ise, Erturan (2020) tarafindan, çarpıcı olarak nitelendirilen değişimlerden birine sahiptir. 650 kilometrelik bisiklet ağı oluşturacağını açılayan kent yönetimi, pandemi sürecinde bu planını pop-up bisiklet yolları ile uygulamaya başlamıştır (Şekil-16).

- Berlin'deki bazı caddelerde bir şerit bisiklet kullanıcılarına ayrılmıştır (Berlin Temporary, 2020) (Şekil-17).

- Budapeşte'de kent merkezindeki ana arterler bisiklet yoluna dönüştürülerek yaya hareketliliğine katkı sağlanmıştır (NACTO, 2020).

-İngiltere'de ise, pandemi sürecinde ve sonrasında bisiklet kullanımının obezite gibi hastalıkları önlemeye yardımcı olacağı belirtilerek sağlık boyutu vurgulamış, bisiklet kullanımının teşvik edilmesi ve kalıcı değişimler yönünde düzenlemeler getirilmiştir (Cyclist Türkiye, 2020).

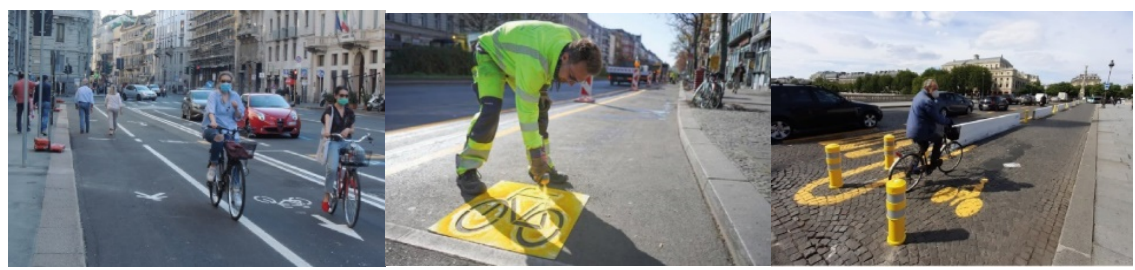

Şekil 15. Milano, Bisiklet Yolu Uygulaması (National Association of City Transportation Officials (Haziran, 2020). Streets for Pandemic Response \& Recovery (s.23).

Şekil 16. Paris, Bisiklet Yolu Uygulaması (Berlin gets 'pop-up' bike lanes to boost cycling in pandemic (2020, 22 Nisan).

Şekil 17. Berlin, Bisiklet Yolu Uygulaması (National Association of City Transportation Officials (Haziran, 2020). Streets for Pandemic Response \& Recovery (s.17).

\section{Dakikalık Şehir Konsepti}

Giderek benimsenen ve bu pandemi sürecinde geliştirilmeye devam eden uygulamalardan biri de "15 dakikalık şehir" konseptidir. Bu konsept sürdürülebilir kent yaklaşımı bağlamımda pandemi öncesi gündeme gelmiş ve pandemi sürecinde geliştirilmiştir.

"15 dakika" fikri, günlük temel ihtiyaçlara en kısa mesafede ulaşmayı sağlayan bir planlama yaklaşımıdır (Çörek Öztaş, 2020) (Şekil 18). Konseptin 
yaklaşımı günlük kentsel hizmetleri geliştirerek aidiyeti arttırmak ve bu bölgeleri merkezileştirmek olarak tanımlanabilir. Diğer amaçları ise kent içerisinde gereksiz seyahatleri azaltmak, daha fazla kamusal alan sağlamak, yaşamı sokakta görmek ve mahalle bazında topluluk hissini güçlendirmek olarak sıralanabilir. Aynı zamanda hareketliliği mikro düzeyde üst seviyeye ç1kararak kriz durumlarında da ulaşım konusunda dayanıklılık sağlamayı hedeflemektedir (Enerji ve Şehir, 2020).

COVID-19 pandemi sürecinde uzaktan eğitim ve evden çalışma gibi uygulamalar da bu konsepti desteklemiştir. Konsept kapsamına yerelde dijitalleşme gibi araçlardan yararlanarak seyahatten kaçınılan; yerelde dükkanların, yeme-içme ve ticari işlevlerin desteklenmesiyle kalkınmanın sağlandığ bir kent yapısı hakimdir. Öte yandan 15 dakikalık şehirler oluşturmak, mahallelerde sokakların ve kamusal alanların yeniden tasarlanması anlamına gelmektedir. Bu durum yürümenin ya da mikro ölçekte ulaşım türü olan bisiklet gibi araçların kullanımını arttıracak ulaşım ağlarının olduğu, otomobil bağımlılığının azaldığı bir hareketlilik anlayışını da gündeme getirmektedir.
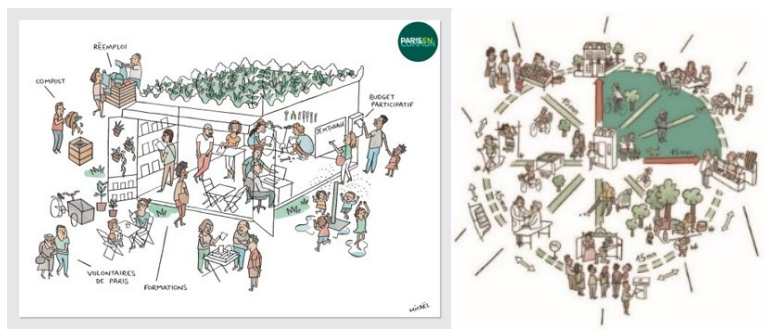

Şekil 18. Paris 15 dakikalık şehir konsepti

(Paris'in "15 Dakikalık Şehir" Olma Hayali (2020, 10 Şubat).

Özellikle pandemi sürecinde sağlıklı mekânlar yaratmanın, kent sakinlerini güvende tutmanın, yerelde oluşabilecek salgınları kontrol altına almanın ve mahalle ölçeğinde bir yaşam sürmenin kritik önemi kanıtlanmıştır $(\mathrm{Xu}$, 2021). 15 dakikalık şehir konsepti dört temel konuda katkı sunmaktadır (C40 Knowledge Hub, 2021):

Yerel ekonomiye destek: Mahalle veya semt ölçeğinde ana caddelerin veya sokakların daha canlı ve işlevsel açıdan çeşitlilik sunabilmesi hedeflenmektedir. Caddelerdeki canlılık daha fazla yaya trafiği ile sağlanırken mahallelerde çeşitli istihdam olanakları yaratılarak sokak mekânı daha verimli kullanılabilir. 
Daha eşitlikçi ve kapsayıcı bir şehir ile güçlü bir topluluk duygusu: Eşitlik ve kapsayıclık cadde ve sokak gibi bir kamusal alanlarda benimsenmesi gereken başlıca ilkelerdendir. 15 dakikalık şehir konsepti ile en savunmasız kullanıcıları da dikkate alarak sokakta aktif hareketlilik için olanaklar sağlanmaktadır. Böylece topluluk içerisinde sosyal bağlar kurulabilmekte ve topluma karışmak, toplumla karşılaşmak için imkânlara sahip olan bir kamusal alan yaratılabilmektedir.

Sağlıklı ve ferah mekânlar: Konsept kapsamında mekânda aktif olarak hareketliliğin devam etmesi ve yeşil alanlar gibi birçok yerel donatı alanına olan mesafenin de kısaltılması hedeflenmektedir. Mesafelerin azalması, günlük hayatta bir ulaşım aracı olarak benimsemenin yanında spor olarak yürüyüş yapmak ve bisiklete binmek için de daha fazla zaman kazandırabilmektedir. Aynı zamanda yerel donatı ve hizmetlerin sağlanması daha fazla ağaç ve daha fazla yeşil alan anlamına da gelmektedir. Bu durumun kentsel isı adası, sel erozyon gibi doğal afet riskleri, biyolojik çeşitliliğin iyileştirilmesi gibi ekolojik açıdan katkıları da bulunmaktadır.

Daha az yolculuk, daha iyi hava kalitesi: 15 dakika stratejisi gereksiz yolculuk ihtiyacını azaltırken aynı zamanda özel araç bağımlılı̆̆ının azaltılmasına da katkı sağlayabilmektedir. Böylece daha yeşil ve sağlıklı hareketlilik ile daha temiz bir hava da sağlanabilmektedir.

Sonuç olarak pandemi süreci, mahalle ölçeğinde donatı ve hizmetlere kısa mesafede ve rahatça erişebilmenin, ekonominin yerelde gelişmesinin, sosyal ve işlevsel açıdan karma kullanımlara sahip olan yaşam alanlarının gerekliliğini bir kez daha göstermiştir. 15 dakikalık şehir konsepti ise tüm bunların önemine vurgu yaparak yaşam ve hizmet alanlarını yerelde ve mahalle ölçeğinde erişilebilir mesafelerde kurgulayıp pandemi gibi kriz durumlarına karşı daha dayanıklı mekânlar yaratmayı amaçlamaktadır.

\section{Kentsel Hareketlilikte Ankara Deneyimleri}

Pandemi, yalnızca kent mekânına ya da mekâna olan algının değil, deneyimin yeniden biçimlendirilmesi sürecinde Türkiye'de kent içi ulaşım sistemlerdeki sorunları daha da açığa çıktığı bir dönem olmuştur. Bunlardan biri de hareketlilik bağlamında, genellikle bireysel ulaşım çözümlerinin benimsenerek özel otomobil kullanımına odaklanılması ile ulaşım altyapısında ve trafikte mevcut yaşanan sorunları daha da arttırmış olmasıdır. Toplum genelinde ve özellikle büyük kentlerde fiziksel mesafenin korunması, diğer yolcu- 
larla temastan kaçınılması ve kalabalık-kapalı bir ortam olması endişesi nedeniyle toplu taşıma araçlarından uzak durulması sonucunda günlük kentiçi yolculuklarda özel otomobil kullanımı daha da artmıştır. Dolayısıyla otomobil kullanımının artması hem hareketliliği hem de özel araç bağımlılığını önemli oranda etkilemiştir. TÜİK verilerine göre, İstanbul özelinde, 20182019 arası yeni kayıt yaptırılan özel araç sayısı \%16 artarken, 2019-2020 arasında bu artış \%64'e yükselmiştir. Toplu taşıma kullanımında ise veriler değerlendirildiğinde \%51'lik bir düşüş yaşanmıştır (TÜİK, 2020). Ankara özelinde ise 2019'da 2 milyon 33 bin 935 iken, 2020 yılında bu say1 2 milyon 158 bin 11'e ulaşmış ve bir önceki yıla (2019) göre yaklaşık \%5 artarak 96.149 araç trafiğe dahil olmuştur (TÜIK, 2020).

Öte yandan otobüs, tramvay, metro gibi toplu ulaşım araçlarını kullanmak istemeyen kent sakinleri tarafından bisiklet kullanımı da görece artmıştır. Ülke genelinde genellikle İstanbul, İzmir, Ankara, Samsun gibi bazı büyük şehirlerde önceki bölümde bazı Dünya örneklerinde de bahsedildiği üzere e-scooter gibi paylaşımlı sistemlerin yanında pop-up bisiklet yolu uygulanmalarına olan talep artmış, "sağlık için tekerlek" gibi çağrılarla birlikte konu ile ilgili halkın farkındalığı yükseltilmeye çalışılmıştır (Cyclist Türkiye, 2020).

Bu bölümde, Türkiye'den pandemi sürecinde Ankara'da yaşanan ulaşım deneyimlerine odaklanılmıştır. Ankara kenti genelinde baskın olan ulaşım türleri arasında metro, Ankaray hafif raylı sistem, EGO ve ÖHA-ÖTA otobüsleri, TCDD banliyö hattı ve dolmuşlar bulunmaktadır. Bu toplu taşıma türleri esas alındığında EGO Yolcu Sayısı verilerine göre COVID-19 pandemisinin ilan edildiği Mart-2020 ayından Nisan-2020 ayına kadar yolcu say1sındaki düşüş \%86 oranındadır. Pandemi sürecinin devam ettiği diğer aylarda yolcu sayılarındaki değişim şekil-19'da görülmektedir.

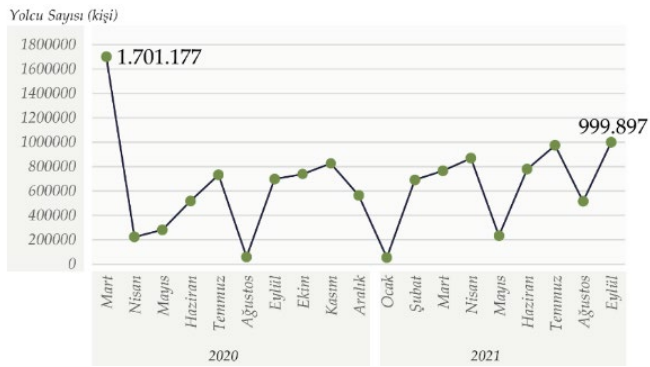

Şekil 19: Mart, 2020-Eylül,2021 ayları arasında Ankara kentinde toplu taşıma sistemlerindeki yolcu değişimi (EGO Genel Müdürlüğü, 2021). (Toplu taşıma türleri: Metro, Ankaray, EGO, ÖHA-ÖTA otobüsleri, TCDD banliyö hattı) (Bu görsel yazarlar tarafından 2021'de oluşturulmuştur.) 
Bununla birlikte kent bütününde mevcutta varolan bir bisiklet ağ sistemi ya da pandemi öncesi planlanmış bir alternatif paylaşımlı sistem bulunmamaktadır. Ancak Şubat 2020 itibariyle Martı e-scooter paylaşımlı sistemi hizmet vermeye başlamıştır. Dolayısıyla pandemi süreci boyunca erişim otobüs, dolmuş ve metro gibi raylı sistemler odaklı olarak sağlanmıştır. Özellikle ilk normalleşme adımları ile iş yerlerinin açılması, üretim faaliyetlerinin devam etmesi ve kamu-özel iş yerlerinin mesai saatlerinin aynı olması toplu taşıma sistemlerinde oldukça tedirgin ve endişeli süreçler yaratmıştır. Otobüs kapasitelerinin azaltılması ile birlikte de yeterli ulaşım aracı sağlanamayıp "korsan dolmuş" gibi sistemler ortaya çıkmıştır. Aynı zamanda dolmuşlar için yetersiz denetimlerin olması da fiziksel mesafenin sağlanamadığ 1 ve belirlenen kapasitenin üzerinde yolcu sayısıyla seyahat edilmesine sebep olmuştur. Dolayısıyla pandemi sürecinde Ankara' da imkânı olan sakinler için özel otomobil kullanımı tercih sebebi haline gelmiştir.

Şekil 20'de paylaşılan Apple hareketlilik raporlarına göre, 2020 yılının Ocak ayından bu yana Ankara genelinde yürüme ile sağlanan ulaşım \%39 azalırken, otomobil ile sağlanan ulaşım ancak \%16 azalabilmiştir (Apple, 2021).

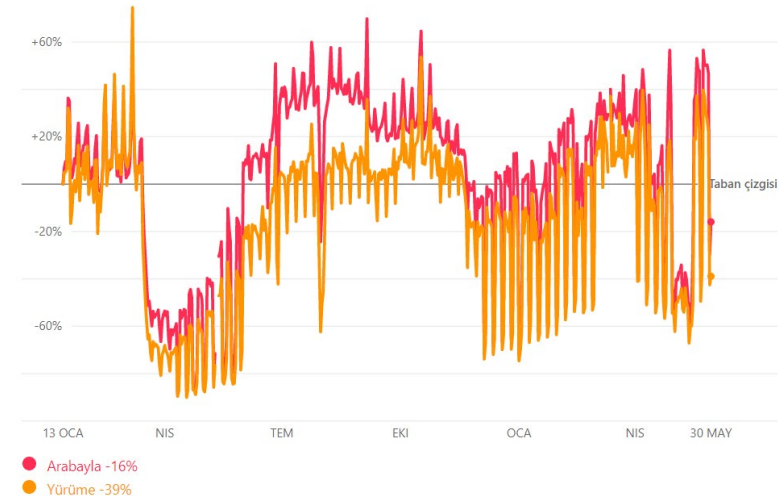

Şekil 20. Apple Hareketlilik Raporlarına Göre Pandemi Sürecinde Ankara (Hareketlilik Trend Raporları (2020, 13 Ocak itibariyle dikkate alınmıştır.)

Yine de pandemi sürecinin başlamasıyla birlikte kent sakinlerinin mahallelerini yeniden keşfettiği ve yaya olarak ulaşım sağladığ miştir. Dolayısıyla kısıtlamalarla birlikte mahalleye sıkışıldığı ve herkesin ihtiyaçlarını mahallelerde ve/veya yakın çevreden karşılamaya çalıştığı bir dönem yaşanmıştır. Ancak mahalle içerisinde yetersiz olan açık ve yeşil alanlardan dolayı kent sakinleri Ankara'nın büyük olarak nitelendirilebilecek parklarında vakit geçirmeye başlamışlardır. Ne var ki bu park ve açık alanlara 
olan erişimin pek çok kullanıcı tarafından özel otomobil ile sağlanması arazi kullanımı ve ulaşım sistemi arasındaki çelişkileri daha da açığa çıkarmıştır.

Ulusal ve uluslararası ölçeklerde gerçekleştirilen pop-up bisiklet yolları, Ankara genelinde uygulanmamıştır. Pandemi öncesi kararı alınan bisiklet ağının bir kısmı, şekil-21'de görüldüğü gibi pandemi sürecinde tamamlanmışır, fakat kısa mesafede hizmete girmesi konut bölgelerinin günlük hayatta yoğun kullanılan metro istasyonları gibi ulaşım noktalarıyla entegre olamaması sebebiyle kent bütününe ve sakinlerine hedeflenen hizmeti verememiştir. Ancak yine de bireysel ulaşım seçimini bisikletten yana kullanmış kent sakinleri olmuştur ve diğer özel otomobiller ve lastik tekerlekli taşıtlar ile aynı yüzeyleri kullanmışlardır. Öte yandan Martı adı verilen e-scooter gibi paylaşımlı sistemler pandemi öncesinde yaygınlaşmaya başladığından süreç içerisinde kullanımları da artmıştır. Dolayısıyla pandemi sürecinde yavaş da olsa yeni ve alternatif sistemler kullanılmaya başlanırken, kent bütünündeki hareketlilik ağırlıklı olarak otomobiller ile gerçekleşmiştir.

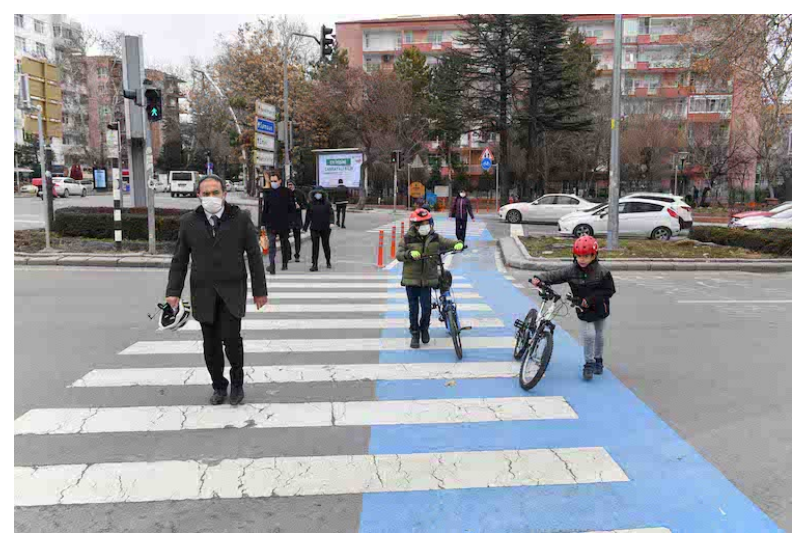

Şekil 21. Ankara, Bahçelievler Tamamlanan Bisiklet Yolu (Başkentte Bisiklet Yolu Ağı Genişliyor (2021, 3 Şubat).

Sonuç olarak bir yandan otobüs ve dolmuş gibi lastik tekerlekli toplu taşıma türlerindeki yoğunlaşma azalmakla birlikte endişe ve kalabalık içerisinde kullanılmaya devam edilmişlerdir. Ancak fiziksel mesafenin korunması ve kapasite ile ilgili uyarılar dikkate alınmaya çalışılmıştır. Otobüs gibi toplu taşıma araçları içinde de gerekli uyarı sistemleri geliştirilmiştir. Öte yandan bisiklet ya da e-scooter gibi sistemlere karşı duyarlılık artmış olsa da 14 Nisan 2021 tarihli “Elektrikli Scooter Yönetmeliği”"nin yayınlaması dışında fizik mekân anlamında bir düzenleme getirilmemiştir. Bir ulaşım türü olarak yürüme düşünüldüğünde ise, mevcut durumdaki yaya yollarının erişim ve 
enkesitler bakımından yetersizliği, düzenleme ve tasarım yönünden eksiklikleri pandemi sürecinde bir kez daha görülmüştür. Kamusal açık mekânlara olan yaya erişiminin kısıtlılığ da belirginleşen problemler arasındadır. Bu kamusal alanlara erişmek için kullanılan ulaşım türü ise özel otomobiller olmuştur. Temel ihtiyaç olarak nitelendirilebilecek açık bir kamusal alana özel otomobil ile ulaşım sağlamak, pandemi sürecinin zorluklarından biri olmuştur. Aynı zamanda toplu taşımaya olan güven eksikliği sebebiyle kent içerisindeki tüm hareketlilik özel otomobillere bağımlı olduğundan pandemi öncesinde yaşanmadığı kadar trafik yoğunluğunun oluştuğu ve bu yoğunluğun hareketliliği azalttı̆̆ süreçler oluşmuştur. Bu durum karbon emisyonu açısından da olumsuz etkileri ortaya çıkarmıştır.

\section{Tartışma ve Sonuç: Post-Pandemi Sürecinde Hareketliliğin Yeniden Düşünülmesi}

COVID-19 pandemi süreci ve bununla birlikte alınan fiziksel mesafe önlemleri, şehirleri şekillendiren güçleri temelden etkilemiştir. Pandemi, insan yoğunluğunun enfeksiyon riskini katlanarak artırmış, kentlerde üretim ve hizmetlerden yararlanmayı zorlaştırmıştır. Bu süreç, kent sakinlerinin sağlığı ile ilgili artan endişelerinin yanısıra kentlerdeki kırılganlıkları ortaya çıkarmış ve gelecekte karşılaşılabilecek problemler ile ilgili de bir kesit sunmuştur. Ulusal ölçekte bakıldığında, ekonomik, ekolojik, sosyal ve fiziksel açıdan kırılganlıklarla baş etmekte zorluklar yaşanmış ve bu zorluklardan biri de kentiçi hareketliliktir. Kentsel hareketlilik ulaşım sistemleriyle sürekli etkileşim içindedir ve uyumlu olmayı gerektirmektedir. Pandemi sürecinde her ne kadar problemler yaşansa da bunun firsata çevirilmeye çalışıldığı bir dönem yaşanmıştır.

İçerisinde bulunduğumuz bilinmezliklerle birlikte, pandemi sürecinin yakın gelecekte sona erme ihtimali olsa da iklim değişikliği, kentsel sağlık, sosyal kapsayıclık ve uyum, rekabetçi ekonomi, yeni yönetişim modelleri ve yenilikçi teknolojiler gibi pandemi öncesi kentsel hareketlilik ile yakından ilişkili ve tartışılan konuların önemini daha da artıracağı beklenmektedir (EIT, 2021) Günümüzde kentler şehir planlaması, kentsel hareketlilik ve kentsel tasarım alanlarında geliştirilen çeşitli stratejik yaklaşımlarla bu zorlukların üstesinden gelmeye çalışmaktadır.

Bu çalışmanın sonucunda COVID-19 sürecindeki stratejiler ve uygulamaları hakkında kentlere yönelik iki durumun ortaya çıtığı görülmüştür: 
- Ankara örneğinde olduğu gibi kentlerin bazılarında uzun vadeli hareketlilik eylem planı ve stratejileri ya henüz bulunmamakta ya da yeniden gözden geçirilmemekte;

- Diğer tarafta ise bazı kentlerde hareketlilik eylem planlarının hazırlanması veya yeniden gözden geçirilmesi için COVID-19 önlemleri itici bir güç olmuştur.

Dolayısıyla ülkeden ülkeye ve şehirden şehire COVID-19 sürecindeki hareketliliğe yönelik stratejiler ve uygulamalar birbirinden farklılık göstermiştir. Örneğin planlama veya altyapısını sağlamakta güçlük çeken kentlerde bütçe kısıtlamaları nedeniyle, pandeminin yarattı̆̆ acil sağlık ihtiyaçlarının üstesinden gelmek için stratejik planların çoğu askıya alınmak zorunda kalırken; kimi kentler yeni hareketlilik projelerini ve/veya sistemlerini dönüştürmek için ortaya çıan firsat penceresinden yararlanarak yeni stratejileri teşvik etmek için süreci lehlerine kullanmışlardır. Öte yandan ikinci yaklaşımı uygulayan kentler pandemi ile radikal değişime uğramamıştır ancak, hareketlilik eylem stratejileri ve ürettikleri çözümlerle sürece daha kısa bir sürede uyumlu hale gelmişlerdir.

Öte yandan pandeminin yarattı̆̆ ekonomik darbenin de iyi anlaşılması gerekmektedir. Önümüzdeki süreçte yeniden ele alınması gereken kentsel altyapı ve düzenlemelerinde, pandeminin kentsel ulaşım ve hareketlilik üzerindeki olası kalıcı etkileri (örneğin kentiçi ulaşımda toplu taşıma kullanımının azalmasına karşılık özel otomobil kullanımının artışını sürdürmesi) hesaba katılmalıdır. Aynı şekilde, bisiklete binme gibi aktif hareketlilik türleri, evden çalışma olasılı̆̆ı nedeniyle yeni konut gereksinimleriyle bağlantılı olmalıdır. Buna ek olarak, e-ticarete geçiş, yeni konut olanakları ve lojistik tarafından da desteklenen kentsel ticarette değişiklikler yaratabilecek potansiyellere de sahiptir. Dolayısıyla tüm bu unsurlar hareketlilik sisteminin nesneleri veya insanları A noktasından B noktasına taşımaktan çok daha fazlası olduğunu ve bir kentsel çevrenin ekonomik gelişimini belirlediğini de ortaya koymaktadır.

Pandemi sürecinden en çok etkilenen ulaşım biçimi olan toplu taşımanın, fiziksel mesafe gibi sebeplerden dolayı, kent içinde kullanılma oranının azaldığı görülmüş̧tür. Pandemi süreci sonrasında da bu oranın uzun bir süre eski kullanım düzeyine ulaşamayacağı tartışılan konular arasındadır. Dolayısıyla toplu taşımayı özendirebilmek için kalite bileşenleri (erişilebilirlik, ulaşım süresi, sefer sayısı gibi) iyileştirilmeli, öncelikli şerit kullanım hakkı tanımlanmalı, toplu taşıma ile bütünleşik ve daha çok mikro ölçekli hareketliliğe hizmet edecek paylaşımlı ulaşım sistemleri (bisiklet, e-scooter, 
yaya gibi) düzeyinde mekânsal, işletme biçimi ve yönetmelikler desteğinde çözümler üretilmelidir. Bu çözümlerin başında, pandemi sürecinde "popup" olarak tasarlanan bisiklet ve yaya yollarının kalıclığının sağlanarak kentle bütünleştirilmesi gelebilir. Yürümek ya da bisiklet kullanarak bir yere erişmek hem toplu taşıma kullanımının tercih edilmemesi sebebiyle ortaya çıkan olumsuz durumları mümkün olduğunca azaltacak hem de günlük ihtiyaçların karşılanabileceği işlevlere erişimde bireysel otomobil kullanımının artmasını ve otomobiller kaynaklı trafik sıkışıklığını önleyecektir.

Pandemi sürecinde de deneyimlendiği gibi, kentlerde odak alınması gereken araç yolları değil insan odaklı ulaşımdır. Her tür koşula sahip birey, yaya olarak yürüme mesafesinde hareket ederek günlük ve temel hizmetlere erişebilmelidir. Yürüme ve bisiklet kullanımını destekleyecek uygulamaların başında motorlu araçlara ayrılan alanların yaya ve bisiklet ulaşımı için de uygun hale getirilmesi gelmektedir. Bu düzenlemeler kapsaminda uygun güzergahlarda bisiklet ve e-scooter şeritlerinin oluşturulması, mahalle merkezleri ve kentin odak noktalarıla bütünleştirilmesi kentsel hizmetlere güvenli bir şekilde yürüyerek erişilebilmesi yer almaktadır.

Pandemi sürecinde mahalle ölçeğinde geçen günlük hayat, donatılar ile ilgili de sorunları bir kez daha göstermiştir. Yürüme mesafesinde açı ve yeşil alanlara ulaşamayan kent sakinlerinin varlığı, kentlerdeki arazi kullanımının yeniden düşünülmesi gerekliliğini ortaya koymuştur. Normalleşme adımları ile birlikte açık ve yeşil alanlara olan erişimin, Ankara örneğinde olduğu gibi, özel otomobil ile sağlandığı durumlar yaşanmıştır. Oysaki iklim krizinin etkilerinin azaltılmasının önemli dinamiklerinden biri mümkün olduğunca düşük karbon salımı olan kentsel hareketliliğe bağlıdır. Kamusal alanlara ve hizmetlere ulaşma konusunda ise arazi kullanım ve verimli ulaşım sistemleri birlikte düşünülmelidir. Bu bağlamda çalışma kapsamında açklanan "15 dakikalık kent" konsepti dikkate alınmalıdır.

Bisiklet, yürüme, e-scooter gibi paylaşımlı sistemler kentsel ulaşımda bir alternatif oluşturarak olası kriz durumunda kentleri daha dayanıklı kılacak ve kriz koşullarına uyumlarını mümkün kılacaktır. Bunun yanında toplu taşıma sistemlerinin iyileştirilmesi, günlük hayatı herkes için kolaylaştıracak eşit ve adil bir şekilde erişimin sağlanması gerekmektedir.

Sonuç olarak, yukarıdaki değerlendirmeler ışığında ve EIT Urban Mobility (2021)'nin “COVID-19 Pandemi Sürecinde Kentsel Hareketlilik Stratejileri" raporu çıarımlarından da yararlanarak bazı önerilerde bulunulabilir. Bunlar: 
- Karar verme aşamasında ulusal ve yerel kaynaklar dikkate alınarak yeni hareketlilik stratejileri ve çözümlerini uygulamak için geniş bir paydaş grubu belirlenmeli ve iş birliği yapılmalıdır.

- Stratejiler geliştirilirken farklı ülke ve kent deneyimlerinden ve iyi uygulamalardan yararlanılmalı, ancak yerel bağlama uyarlanmalıdır. Bu bağlamda çalışmada ele alınan iyi uygulamalardan çıarılacak dersler kentlerde hareketlilik ve seyahat davranışlarını değerlendirme araçlarına dönüştürülebilme potansiyeli de sunmaktadır.

- Toplu taşıma sistemi daha esnek mikro-hareketlilik seçenekleriyle bütünleştirilmelidir. Paylaşımlı sistemlere açık olan düzenleyici yaklaşımlar, ekonomik uygulanabilirliği içerecek ve hareketlilik sisteminde ihtiyaç duyulan esnekliği artıracaktır.

- Kentsel hareketlilik sistemlerini yeniden şekillendirmek için uzun vadeli firsatlar olarak yayalar için engelsiz ve evrensel erişilebilirlik ilkelerine uygun yol alanı düzenlemeleri yeniden gözden geçirilmelidir.

- Sürdürülebilir ulaşım türleri için daha büyük bir kamusal alan payı tahsis etmek ve pandeminin getirdiği otomobil kullanımı ağırlıklı hareketliliğin üstesinden gelmek için dijital altyapıya sahip Bir Hizmet olarak Hareketlilik (MaaS) gibi tamamlayıcı ve kapsayıcı seyahat talebi yönetim araçları eşlik etmelidir. Bununla birlikte "Hareketlilik Eylem Plan ve Stratejileri" (SUMP) ulusal ve yerel/kent ölçeğindeki ulaşım planlarına entegre edilmeli, dolayısıyla bütünleşik ele alınmalıdır. 


\section{Extended Abstract}

\section{Urban Mobility During the COVID-19 Pandemic: Examples of World and Experiences from Ankara}

\author{
Şerife Özcan \\ ORCID: 0000-0003-3268-1528
}

\author{
Cenk Hamamcıoğlu \\ ORCID: 0000-0002-3872-4608
}

Although urban mobility is defined as all of the daily journeys, it is realized as a result of the needs of the city residents and the demand for travel. Therefore, it includes the safe, fast and affordable travel of individuals and loads in the city as well as moving in harmony with the environment, and it is a multi-factor complex area that establishes relationships and varies in the context of cities' land use, urban forms, transportation systems, socioeconomic structures (Peralta-Quiros, 2015; Wee \& Handy, 2016; Meyer, Jan Hoekstra ve Westrik, 2020; Rodrigue, 2020).

The spread of the COVID-19 pandemic from the city of Wuhan in December, 2019 has had dramatic effects on daily life. Daily lifestyles have changed with concepts such as complete closure or distance and urban mobility has been one of the situation that have been reshaped. The decrease in public activities and mobility due to applications such as working from home, distance learning, e-shopping, especially during the closure process, has led to a period in which the demand for transportation and public transportation vehicles declines (De Vos, 2020). Although new rules were developed in public transportation systems with the adoption of return to normal life strategies in the following process, there were trips where health concerns such as the high number of users and the inability to maintain physical distance occurred. As a result, many people tried to meet their transportation needs by using private vehicles at a higher rate than before the pandemic.

The common principle of the solutions produced with the partnerships of municipalities and private companies in many cities has been the realization 
of route arrangements by allocating more space in the street and avenue cross sections for pedestrians and cyclists with the support of legal regulations, and providing more opportunities in micro-mobility scale such as e-scooters. As a result of many people avoiding public transportation and turning to bicycle transportation, "pop-up" bicycle paths were built in many cities, which are quickly implemented and most of them are defined as temporary. In this context, the street space has also turned into a public space used for various functions. Many cities have turned to concepts such as shared, slow, open, spacious streets by partially closing their streets to vehicle traffic and supporting the usability of individual and shared mobility systems.

At the same time, life has turned into a neighborhood scale for those who stay at home, work remotely and receive education. In this process, where most of the daily needs are met from close distances and the importance of finding urban services that can be accessed within walking distance has been emphasized. In this context, the 15-minute city concept was developed during the pandemic. The idea of 15 minutes is an approach based on reaching the daily basic needs in the shortest distance, supporting the centralization of many regions, thus reducing unnecessary travel, and thus aiming to provide resilience in transportation as a result of reducing automobile dependence (Enerji ve Şehir, 2020).

Looking at the pandemic process in the city of Ankara, as for walking as a mode of transportation, the inadequacy of the existing pedestrian roads in terms of access and cross-sections, deficiencies in terms of arrangement and design have been seen once again during the pandemic process, and systems such as bicycles and e-scooters have been used as an individual solution. Although the limitation of pedestrian access to public open spaces is among the problems that have become evident, transportation to open and green spaces is provided by private cars. However, one of the important dynamics of reducing the effects of the climate crisis depends on urban mobility, which has as low carbon emissions as possible. In terms of accessing public spaces and services, land use and efficient transportation systems should be considered together. In this context, the concept of "15-minute city" explained within the scope of the study should be taken into consideration.

During the pandemic process, some arrangements have been made in urban space and transportation systems in order to make mobility healthy, safe and possible for everyone, both on a national scale and in cities around the world. The aim of this article is to share the experiences of urban mobility from around the world, the approaches developed, the arrangements made 
in line with the changing travel behaviors during the pandemic process, and to suggest ideas to local governments for cities in Turkey and Ankara. In the paper, firstly, the concept of urban mobility was explained with the support of the literature. Then, the study of Cardell and Batra, who shared the rates of different cities, was taken into account in order to reveal how much mobility was affected during the pandemic process, then, examples of good practices included in the "Urban Mobility Strategies report in the COVID-19 Pandemic Process" dated 2021 prepared by the Urban Mobility (EIT Urban Mobility) unit of the European Institute of Innovation and Technology, affiliated with the European Union, were used. Afterwards, the city of Ankara was handled in the context of urban mobility during the pandemic process, and the experiences in this process were conveyed. With the help of this report data, examples and experiences as well as the compilation of the news in the media, it has been tried to shed light on the travel behaviors that started to change albeit slowly, with the introduction of alternative and innovative modes of transportation.

In order to turn the crises experienced during the pandemic process into opportunities in the post-pandemic period, new mobility strategies should be adopted; while developing strategies, different country and city experiences and good practice examples should be used, but adapted to the local context. Collective mobility solutions should be based on and in this context, public transportation systems should be improved and integrated with micromobility options. Thus, equal and fair accessibility can be achieved with integrated urban mobility systems and integrated spatial planning that will facilitate the flow of daily life for everyone, even in difficult conditions such as pandemics.

\section{Kaynakça/References}

15 dakikalık şehir nedir? Nasıl inşa edilir? (2020). Enerji ve Şehir. 7 Mayıs 2021 tarihinde http://enerjivesehir.com/index.php/yerel_yonetimler/15-dakikalik-sehir-nedir-nasilinsa-edilir/ adresinden erişildi.

Alyavina, E., A Nikitas, A. ve Njoya, E.T. (2020). Mobility as a service and sustainable travel behaviour: A thematic analysis study. Transportation Research Part F 73, 362-381. 
Apple hareket raporları, (2021). 4 Mayıs 2021 tarihinde https://covid19.apple.com/mobility adresinden erişildi.

Avrupa İstatistik Ofisi, nüfus verileri (2018). 16 Temmuz 2021 tarihinde https://ec.europa.eu/eurostat adresinden erişildi.

Başkentte bisiklet yolu ağı genişliyor (2021). Ankara Büyükşehir Belediyesi. 7 Mayıs 2021 tarihinde, https://ankara.bel.tr/haberler/baskentte-bisiklet-yolu-agi-genisliyor/ adresinden erişildi.

Berlin gets 'pop-up' bike lanes to boost cycling in pandemic (2020). 7 On Your Side. 10 Temmuz 2021 tarihinde, https://katv.com/news/coronavirus/berlin-gets-popup-bike-lanes-to-boost-cycling-in-pandemic adresinden erişildi.

Bicycles for Tartu's bicycle sharing system coming from Canada (2021). Tartu Linn. 22 Nisan 2021 tarihinde, https://www.tartu.ee/ru/node/7509 adresinden erişildi.

Boris Johnson, ülkesinde bisikletin yaygınlaştırılması konusunda "1srarcı" davranıyor (2020). Cyclist Türkiye. 8 Mayıs 2021 tarihinde, https://www.cyclistmag.com.tr/2020/05/15/boris-johnson-ulkesinde-bisikletin-yayginlastirilmasi-konusunda-israrci-davraniyor/ adresinden erişildi.

Camagni, R., Gibelli, M.C. ve Rigamonti, P. (2002). Urban mobility and urban form: The social and environmental costs of different patterns of urban expansion. Special Selection: Economic of Urban Sustainability, Ecological Economics, 40, 199216.

Cardell, M., Batra, G. (2020). How mobility can help build a better post COVID-19 world. Ernst \& Young Global Limited (EY). 10 Nisan 2021 tarihinde, https://www.ey.com/en_gl/automotive-transportation/how-mobility-canhelp-build-a-better-post-covid-19-world adresinden erişildi.

Coronavirus: Rome public transport in phase two (2020). Wanted in Rome. 4 Mayis 2021 tarihinde,

https:/www.wantedinrome.com/news/coronavirus-rome-public-transport-in-phasetwo.html adresinden erişildi.

Costa P., B., Morais Neto G.C. ve Bertolde A.I. (2017). Urban mobility indexes: A brief review of the literatüre. Transportation Research Procedia, 25, 3645-3655.

Cycling in Lund (2020). Lunds Kommun. 21 Haziran 2021 tarihinde, https://www.lund.se/en/transport--spatial-planning/cycling-in-lund/ adresinden erişildi.

Daizong L., Lulu X. ve Tina H. (2020). 3 ways China's transport sector is working to recover from COVID-19 lockdowns. The City Fix Türkiye. 27 Haziran 2021 tarihinde, https://thecityfix.com/blog/3-ways-chinas-transport-sector-workingrecover-covid-19-lockdowns/ adresinden erişildi.

De Vos, J. (2020). The effect of COVID-19 and subsequent social distancing on travel behavior. Transportation Research Interdisciplinary Perspectives, 5, 100121.

EGO Genel Müdürlüğü, günlük yolcu sayıları verisi (2021). 28 Kasım 2021 tarihinde, https://www.ego.gov.tr/tr/sayfa/2257/gunluk-yolcu-sayilari adresinden erişildi. 
EIT Urban Mobility (2021). Best practices for resilient $\mathcal{E}$ future proof urban mobility systems. Full Report: Urban Mobility Strategies During COVID-19.

Erturan, A. (2020). Pandemi ve post-pandemide kentlerimizde nasıl ulaşacağız? Spektrum Dergisi, 2, 93-97.

Estonya İstatistik Kurumu, nüfus verileri (2017). 16 Temmuz 2021 tarihinde, https://www.stat.ee adresinden erişildi.

Estonya'da bir ana cadde arabalardan arındırıldı (2020). Eko Yapı Dergisi. 16 Temmuz 2021 tarihinde,

https://www.ekoyapidergisi.org/estonya-da-bir-ana-cadde-arabalardan-arindirildi adresinden erişildi.

From transport towards environmentally friendly participation in urban life (2021). Connective Cities. 16 Temmuz 2021 tarihinde, https://www.connective-cities.net/en/topics/integrated-urban-development/urban-transport-and-mobility adresinden erişildi.

Gakenheimer, R. (1999). Urban mobility in the developing world. Transportation Research Part A, 33, 671-689.

Georgakis, P., Almohammad, A., Bothos, E., Magoutas, B., Arnaoutaki, K. ve Mentzas, G. (2020). Heuristic-based journey planner for mobility as a service (MaaS). Sustainability 2020 12, 1-25.

Google COVID-19 topluluk hareket raporları (2020). 4 Mayıs 2021 tarihinde, https:/www.google.com/covid19/mobility/ adresinden erişildi.

Gürsoy, O. (2021). Pandeminin kentsel hareketliliğe etkisi ve akıllı şehirler için uygulama firsatları. Spektrum Dergisi, 2, 19-23.

Hensher, D.A. (2020). What might COVID-19 mean for mobility as a service (MaaS). Transport Reviews, 40(5), 551-556.

IGI Global Dictionary Search (2021). 16 Temmuz 2021 tarihinde, https://www.igi-global.com adresinden erişildi.

İzmir'e yeni bisiklet yolları geliyor. (2020). Cyclist Türkiye. 8 Mayıs 2021 tarihinde, https://www.cyclistmag.com.tr/2020/05/20/izmire-yeni-bisiklet-yollari-geliyor/ adresinden erişildi.

Jones, P. (2014). The evolution of urban mobility: the interplay of academic and policy perspectives. IATSS Research, 38(1), 7-13.

Karahan Kamacl, E. (2021). Kent-içi hareketlilik: 5N1K. Spektrum Dergisi, 2, 1-5.

Koronavirüsle mücadelede 'İsveç modeli' işe yarar mı? (2020). BBC News Türkçe. 21 Ağustos 2021 tarihinde,

https://www.bbc.com/turkce/haberler-dunya-52083153 adresinden erişildi.

Macharis, C. ve Keseru, I. (2018). Rethinking mobility for a human city. Transport Reviews, 38(3), 275-278.

Marino, G.C. (2020). A woman in a face mask rides a bicycle while another woman rides past on a railway bridge in Rome, Italy. Unsplash. 20 Haziran 2021 tarihinde, https://unsplash.com/photos/Hk5Io94h0KM adresinden erişildi. 
Matyas, M. ve Kamargianni, K. (2017). Stated preference design for exploring demand for mobility as a service plans. Presented at 5th International Choice Modelling Conference, Cape Town, April 3-5.

May, A. D. (2015). Encouraging good practice in the development of sustainable urban mobility plans. Case Studies on Transport Policy, 3(1), 3-11.

Milne, G. J. ve Xie, S. (2020). The effectiveness of social distancing in mitigating COVID-19 spread: A modelling analysis.

Meyer, H., Jan Hoekstra, M., ve Westrik, J. (2020). Urbanism fundamentals and prospects. Delft: Boom Uitgevers Amsterdam.

Mobilità Elettrica (2021). 29 Ağustos 2021 tarihinde https://romamobilita.it/it/muoversiaroma/elettrico adresinden erişildi.

National Association of City Transportation Officials (2020). Streets for pandemic response \& recovery. 4 Mayss 2021 tarihinde, https://nacto.org/publication/streets-for-pandemic-response-recovery adresinden erişildi.

Litman, T. ve Burwell, D. (2006). Issues in sustainable transportation. International Journal of Global Environmental Issues, 6(4), 331-347.

Leo, A., Morillon, D. ve Silva, R. (2017). Review and analysis of urban mobility strategies in Mexico. Case Studies on Transport Policy, 5(2), 299-305.

Öztaş Çörek, Ç. (2020). Sürdürülebilir ulaşım ve COVID-19 sonrası yeni ulaşım perspektifleri. The City Fix Türkiye. 16 Temmuz 2021 tarihinde, https://thecityfixturkiye.com/surdurulebilir-ulasim-ve-covid-19-sonrasi-yeni-ulasim-perspektifleri/ adresinden erişildi.

Paris'in "15 dakikalık şehir" olma hayali (2020) Yapı Dergisi. 28 Nisan 2021 tarihinde, http://www.yapi.com.tr/haberler/parisin-15-dakikalik-sehir-olma-hayali_177538.html adresinden erişildi.

PEARL-Peer Experience and Reflective Learning (2015). Urban mobility. NUIA: Compendium of Global Good Practices 2-6.

Peralta-Quiros, T. (2015). Mobility for all: Getting the right indicator, shifting from the proximity of transport to the accessibility of opportunities. Connections Transport \& ICT, The World Bank.

Rodrigue, J. P. (2020). The geography of transport systems. New York: Routledge.

Shaheen, S., Cohen, A., Broader, J., Davis, R., Brown, L., Neelakantan, R. ve Gopalakrishna, D. (2020). Mobility on demand planning and implementation: current practices, innovations, and emerging mobility futures. Transportation Sustainability Research Center University of California, Berkeley and U.S. Department of Transportation Washington, DC.

The Berlin pop-up bike lanes (2020). Euronews Next. 4 Mayis 2021 tarihinde, nrvp.de/22856 adresinden erişildi.

TÜİK-Türkiye İstatistik Kurumu (2020). Motorlu Kara Taşıtlarl, Aralık 2020 Raporu.

Wang, L. (2020). Tartu turns a major street into a car-free haven for a month. INHabitat. 18 Ağustos 2021 tarihinde, 
https://inhabitat.com/tartu-turns-a-major-street-into-a-car-free-haven-for-a-month/ adresinden erişildi.

Wee B.V. ve Handy, S. (2016). Key research themes on urban space, scale, and sustainable urban mobility. International Journal of Sustainable Transportation, 10(1), 18-24.

Why every city can benefit from a '15-minute city' vision. (2021). C40 Knowledge Hub. 7 Mayıs 2021 tarihinde,

https://www.c40knowledgehub.org/s/article/Why-every-city-can-benefit-from-a-15minute-city-vision?language=en_US\#: :text=Lower\%20transport\%20emissions\%20and\%20better,healthy\%20transport\%20and\%20cleaner\%20air adresinden erişildi.

Xu, Y. (2021) What is a 15-minute city and why is it important? Chapman Taylor. 7 May1s 2021 tarihinde,

https://www.chapmantaylor.com/insights/what-is-a-15-minute-city-and-why-is-itimportant adresinden erişildi. 